Maffulli N, Caine DJ (eds): Epidemiology of Pediatric Sports Injuries: Team Sports.

Med Sport Sci. Basel, Karger, 2005, vol 49, pp 86-119

\title{
Ice Hockey Injuries
}

\author{
Brian W. Benson, Willem H. Meeuwisse \\ Faculty of Kinesiology, Sport Medicine Centre and \\ Department of Community Health Sciences, \\ Faculty of Medicine, University of Calgary, Calgary, Alberta, Canada
}

\begin{abstract}
Objective: This article reviews the distribution and determinants of injuries reported in the pediatric ice hockey literature, and suggests potential injury prevention strategies and directions for further research. Data Sources: Thirteen electronic databases, the ISI Web of Science, and 'grey literature' databases were searched using a combination of Medical Subject Headings and text words to identify potentially relevant articles. The bibliographies of selected studies were searched to identify additional articles. Studies were selected for review based on predetermined inclusion and exclusion criteria. Main Results: A comparison between studies on this topic area was difficult due to the variability in research designs, definition of injury, study populations, and measurements used to assess injury. The majority of injuries were sustained during games compared with practices. The two most commonly reported injuries were sprains/strains and contusions. Players competing at the Minor hockey, High School, and Junior levels of competition sustained most of their injuries to the upper extremity, head, and lower extremity, respectively. The primary mechanism of injury was body checking, followed by stick and puck contact. The frequency of catastrophic eye injuries has been significantly reduced with the world-wide mandation of full facial protection for all Minor hockey players. Conclusions: Specific hockey-related injury risk factors are poorly delineated and rarely studied among pediatric ice hockey players leaving large gaps in the knowledge of appropriate prevention strategies. Risk management strategies should be focused at avoiding unnecessary foreseeable risk, and controlling the risks inherent to the sport. Suggestions for injury prevention and future research are discussed.
\end{abstract}

Copyright (C) 2005 S. Karger AG, Basel

\section{Introduction}

Ice hockey is one of Canada's most popular sports, with more than 500,000 registered players in the Canadian Hockey Association [1]. In the United States, more than 18,000 teams and 200,000 children are currently registered with 
USA Hockey [2-4]. In Finland, there are 60,000 registered ice hockey players in a population of five million people, with 45,000 under 19 years of age [5]. Ice hockey is a skilled team sport that has many individual benefits for children and adolescents, including leadership development, team building, discipline, camaraderie, sportsmanship, fun, and cardiovascular conditioning. On the other hand, it is a contact/collision sport that has several inherent features that predispose athletes to injury such as high acceleration and deceleration forces, changing directions, body checking, razor-sharp skates, aggressive stick use, hard rubber projectiles, rigid boards, and a low-friction ice surface. Skating and puck velocities of 32 and $80 \mathrm{~km} / \mathrm{h}$, respectively, have been documented for peewee players (age 12 years) [6]. Such characteristics result in frequent highimpact collisions between players, as well as forceful impacts with the side boards, goal posts, pucks, and hockey sticks.

Recently, concern has been expressed, both public and professional, about the increased frequency of injuries in youth leagues that permit body checking, especially as players become bigger, stronger, and faster [1]. At all levels of competition, hockey associations world-wide have tried to reduce the frequency of injuries through rule changes, strict rule enforcement, stiffer penalties for illegal play, enhanced coaching techniques, and the mandation of protective equipment. None of these strategies, however, has been uniformly implemented, primarily because of a lack of scientific evidence to support their effectiveness in reducing injury and philosophical debates among administrators.

This article reviews the distribution and determinants of injuries reported in the pediatric ice hockey literature, and suggests potential injury prevention strategies and directions for further research.

Thirteen electronic databases were searched using a combination of Medical Subject Headings and text words by means of 'wild cards' and Boolean operators to identify potentially relevant English and non-English articles. The search strategy administered was as follows: (1) injur\$ OR (athletic injur\$) [all fields], AND (2) (child\$ OR adolesc\$ OR pediatric) [all fields], AND (3) (random\$ OR (controlled trial\$) OR prospectiv\$ OR cohort OR control\$ OR compar\$ OR (follow-up) OR volunteer\$ OR risk OR inciden\$ OR rate OR case\$ OR cross-section\$ OR survey OR questionnaire) [all fields], AND (4) (hockey\$ OR (ice hockey\$)) [all fields]. The electronic databases and number of citations identified using a combination of the above search strategies are shown in table 1. In addition, the Science Citation Index (1981-2004), Social Sciences Citation Index (1981-2004), and Arts \& Humanities Citation Index (1981-2004) databases (ISI Web of Science, 1975 to May 2004) were searched by entering a commonly referenced original study [7] pertaining to the topic of interest. Furthermore, 'grey literature' databases and resources were searched, including Dissertations Abstracts (http://www.ucalgary.ca/library/gateway/indabs.html), 
Table 1. Electronic search strategy with number of identified citations

\begin{tabular}{|c|c|c|c|}
\hline Electronic database & Search strategy & $\begin{array}{l}\text { Number of } \\
\text { citations }\end{array}$ & $\begin{array}{l}\text { Number of } \\
\text { potentially } \\
\text { relevant } \\
\text { citations }\end{array}$ \\
\hline $\begin{array}{l}\text { MEDLINE (1966-April } 2004 \\
\text { week 5) }\end{array}$ & $\begin{array}{l}1 \text { AND } 2 \text { AND } \\
3 \text { AND } 4\end{array}$ & 156 & 48 \\
\hline HealthSTAR (1975-April 2004) & $\begin{array}{l}1 \text { AND } 2 \text { AND } \\
3 \text { AND } 4\end{array}$ & 126 & 45 \\
\hline $\begin{array}{l}\text { SportDiscuss (1830-1997), } \\
\text { (1998-Oct 2003) }\end{array}$ & $\begin{array}{l}1 \text { AND } 2 \\
\text { AND } 4\end{array}$ & 108 & 22 \\
\hline EMBASE (1980-2004 week 20) & $\begin{array}{l}1 \text { AND } 2 \text { AND } \\
3 \text { AND } 4\end{array}$ & 82 & 32 \\
\hline PubMed (1966-March 2004) & $\begin{array}{l}1 \text { AND } 2 \text { AND } \\
3 \text { AND } 4\end{array}$ & 181 & 45 \\
\hline CINAHL (1982-May 2004 week 1) & $\begin{array}{l}1 \text { AND } 2 \text { AND } \\
3 \text { AND } 4\end{array}$ & 125 & 14 \\
\hline OLDMEDLINE (1951-1965) & $\begin{array}{l}1 \text { AND } 2 \text { AND } \\
3 \text { AND } 4\end{array}$ & 0 & 0 \\
\hline $\begin{array}{l}\text { Biological Abstracts } \\
(1980-\text { March 2004) }\end{array}$ & $\begin{array}{l}1 \text { AND } 2 \text { AND } \\
3 \text { AND } 4\end{array}$ & 26 & 15 \\
\hline $\begin{array}{l}\text { AMED - Allied and Complementary } \\
\text { Medicine (1985-May 2004) }\end{array}$ & $\begin{array}{l}1 \text { AND } 2 \text { AND } \\
3 \text { AND } 4\end{array}$ & 1 & 1 \\
\hline $\begin{array}{l}\text { Cochrane Database of Systematic } \\
\text { Reviews (1st Quarter 2004) }\end{array}$ & $\begin{array}{l}1 \text { AND } 2 \\
\text { AND } 4\end{array}$ & 3 & 0 \\
\hline $\begin{array}{l}\text { ACP Journal Club } \\
\text { (1991 to Jan/Feb 2004) }\end{array}$ & $\begin{array}{l}1 \text { AND } 2 \text { AND } \\
3 \text { AND } 4\end{array}$ & 0 & 0 \\
\hline $\begin{array}{l}\text { Database of Abstracts of Reviews } \\
\text { of Effects (1st Quarter 2004) }\end{array}$ & $\begin{array}{l}1 \text { AND } 2 \\
\text { AND } 4\end{array}$ & 0 & 0 \\
\hline $\begin{array}{l}\text { Cochrane Central Register of } \\
\text { Controlled Trials (1st Quarter 2004) }\end{array}$ & $\begin{array}{r}1 \text { AND } 2 \\
\text { AND } 4\end{array}$ & 0 & 0 \\
\hline
\end{tabular}

Health Canada (http://www.hc-sc.gc.ca/english/ index.htm), and general internet searching via Google. Lastly, the bibliographies of the selected articles were hand-searched to identify additional articles not identified using the above search strategies.

\section{Selection Criteria}

The following predetermined inclusion criteria were used to select relevant studies: (1) original data (cross-sectional, case series, case control, prospective cohort, quasi-experimental, and randomized controlled trials); (2) injuries sustained in the sport of ice hockey; (3) injuries sustained by children 18 years 
or younger; (4) male or female athletes; (5) athletes participating at all levels of competition; (6) peer-reviewed reports/articles; and (7) English language. Exclusion criteria were as follows: (1) studied injuries related to congenital anomalies; (2) studied injury rates among a broad age spectrum of athletes, including pediatric and adult hockey players; (3) review articles, commentaries, case reports, letters to the editor, and anecdotal reports; (4) studied specific injuries over a broad range of sport settings (i.e., study not exclusive to the sport of ice hockey); and (5) non-English articles. Because there was a scarcity of peer-reviewed studies pertaining to ice hockey injuries on children 18 years of age and younger, we included studies reporting injuries among athletes participating at the Junior level of competition (ages 15-20 years).

The titles and abstracts (when available) of the identified citations were screened by one investigator to identify all potentially relevant articles. If insufficient information was available (e.g., no abstract), the full papers were reviewed for inclusion based on the predetermined selection criteria. A comparison between studies on this topic area was difficult because of the following limitations:

- The majority of studies were observational descriptive, with very few analytical designs.

- The definition of the outcome variable (i.e., injury) was not clearly stated in several of the selected studies. For example, an overestimation of injury rates may occur if all injuries were reported, regardless of the reporting source (e.g., coach, parent). In addition, questionnaires with no clearly stated injury definition may underestimate injury rates if athletes were required to self-report injuries retrospectively, especially if no time loss from participation was experienced. Furthermore, concussion rates would be significantly underestimated if they were defined as 'any loss of consciousness experienced by a player during contact, whether a momentary loss of consciousness or an amnesia-type disorder' because greater than $90 \%$ of sport-related concussions do not result in loss of consciousness [8].

- Data collection methods ranged from self-report to insurance claim, coach, therapist, and physician report.

- The validity of the recording mechanisms was unknown in the majority of studies pertaining to the topic of interest.

- The study populations were generally small, with no reported sample size or power calculations.

- There was no standardization of injury incidence (e.g., injuries per 1,000 athlete-exposures or 1,000 player-hours) in several studies, and individual participation (exposure) information was rarely collected; this is critical for the assessment of risk. 
- Study populations were predominantly samples of convenience with no random selection of subjects, a source of selection bias.

- Individual baseline injury history was not reported in several studies; this may have resulted in an overestimation of injury rates if the athletes selected were more likely to be injured based on their previous injury history (that is, if there was differential participation).

- There was no report of subject drop-outs or loss to follow-up in several of the selected studies; this may have lead to an underestimation of association between specific risk factors and injury (if the reason for drop-out was related to the injury itself).

- A significant source of bias in the reviewed studies was a lack of measurement and control for potentially confounding variables. Differences in coaching techniques, musculature and cardiovascular conditioning, warm-up routines, protective equipment use, rules, rule enforcement, age, experience level, skill level, position, previous injury history, venue type (i.e., practice vs. game), and arena characteristics may all have a significant effect on the results.

- External validity of the results in several of the selected studies was limited due to the lack of internal validity.

\section{Incidence of Injury}

Incidence is defined by Last [9] as 'the number of new events, e.g., new cases of a disease [or injury in this case] in a defined population, within a specified period of time'. Incidence rate is 'the rate at which new events occur in a population. The numerator is the number of new events that occur in a defined population; the denominator is the population at risk of experiencing the event during this period, sometimes expressed as person-time' [9].

Table 2 highlights a comparison of injury rates among ice hockey players participating at the Junior level of play and under [2, 3, 5, 7, 10-29]. As shown in the table, there was a wide range of injury rates reported in the studies selected for review. It was impossible to give a single approximation or range for the rate of ice hockey injuries sustained. This can be attributed to differences in study design (prospective vs. retrospective), differences between the sample population at risk of injury (e.g., associations, leagues, age groups, levels of play, equipment rules, and officiating rules), different sources of injury collection (e.g., players, coaches, trainers, therapists, physicians, emergency department visits, insurance claims, databases), different methods for measuring athlete participation (exposure) time (e.g., estimation vs. direct observation; player-hours, athlete-exposures), different methods of calculating 
Table 2. A comparison of injury rates among pediatric ice hockey players

\begin{tabular}{|c|c|c|c|c|c|c|c|c|c|c|c|}
\hline \multirow[t]{2}{*}{ Level/Study } & \multirow{2}{*}{$\begin{array}{l}\text { Design } \\
\mathrm{P} / \mathrm{R}\end{array}$} & \multirow{2}{*}{$\begin{array}{l}\text { Injury } \\
\text { collection } \\
\text { (source) }\end{array}$} & \multirow{2}{*}{$\begin{array}{l}\text { Age } \\
\text { (years) }\end{array}$} & \multirow{2}{*}{$\begin{array}{l}\text { Duration of } \\
\text { study(number } \\
\text { of seasons } \\
\text { and year) }\end{array}$} & \multirow{2}{*}{$\begin{array}{l}\text { Sample } \\
\text { number of } \\
\text { subjects }\end{array}$} & \multirow{2}{*}{$\begin{array}{l}\text { Sample } \\
\text { number } \\
\text { of teams }\end{array}$} & \multirow{2}{*}{$\begin{array}{l}\text { Number of } \\
\text { injuries }\end{array}$} & \multicolumn{4}{|l|}{ Injury rate } \\
\hline & & & & & & & & $\begin{array}{l}\text { injuries } \\
\text { per game }\end{array}$ & $\begin{array}{l}\text { injuries per } \\
100 \text { players }\end{array}$ & $\begin{array}{l}\text { injuries } \\
\text { per } 1,000 \mathrm{~h}\end{array}$ & $\begin{array}{l}\text { injuries per } \\
1,000 \mathrm{~A}-\mathrm{E}\end{array}$ \\
\hline \multicolumn{12}{|l|}{ Junior } \\
\hline [2] & $\mathrm{P}$ & $\begin{array}{l}\text { Trainer } \\
\text { and MD }\end{array}$ & $17-20$ & $3(1990-1993)$ & 25 & 1 & 142 & & & 9.4 & \\
\hline [10] & $\mathrm{P}$ & $\begin{array}{l}\text { MD and } \\
\text { trainers }\end{array}$ & $\begin{array}{l}16-20 \\
(?)\end{array}$ & 1 & 22 & 1 & 74 & & Fwd: 138 & Games & \\
\hline [21] & $\mathrm{P} / \mathrm{R}$ & $\begin{array}{l}\text { Trainers, } \\
\text { coaches, } \\
\text { MDs }\end{array}$ & $15-20$ & $2(1998-2000)$ & $\begin{array}{l}\text { Year 1: } 272 \\
\text { Year 2: } 283\end{array}$ & 14 & $\begin{array}{l}\text { Year 1: } 29 \\
\text { Year 2: } 21\end{array}$ & & $\begin{array}{l}\text { Year 1: } 10.7 \\
\text { Year 2: } 7.42\end{array}$ & $\begin{array}{l}\text { Def: } 151 \\
\text { Games } \\
\text { Year 1: } 5.95 \\
\text { Year 2: } 4.63\end{array}$ & \\
\hline [13] & $\mathrm{P}$ & $?$ & $15-19$ & $1(1977-1978)$ & $?$ & 1 & 83 & & & & \\
\hline$[22]$ & $\mathrm{P}$ & Trainers & $16-21$ & $\begin{array}{l}1 \\
?\end{array}$ & 282 & 10 & $\begin{array}{l}\text { Head, neck, } \\
\text { face only } \\
113\end{array}$ & & & $\begin{array}{l}\text { NFS: } 158.9 \\
\text { HS: } 73.5 \\
\text { FS: } 23.2\end{array}$ & \\
\hline [16] & $\mathrm{R}$ & $\begin{array}{l}\text { Trainer and } \\
\text { athletic } \\
\text { therapists }\end{array}$ & $16-20$ & $1(1993-1994)$ & $?$ & 16 & 328 & $\begin{array}{l}\text { LTS: } 0.33 \\
\text { S: } 0.58 \\
\text { STS: } 0.76\end{array}$ & & & \\
\hline \multicolumn{12}{|l|}{ High School } \\
\hline [7] & $\mathrm{R}$ & Quest. & $\begin{array}{c}\text { Mean } \\
16.1\end{array}$ & $1(1982-1983)$ & 251 & 12 & $\begin{array}{l}75 \text { per } 100 \\
\text { players }\end{array}$ & & 75 & 5 & \\
\hline [17] & $\mathrm{P}$ & $\begin{array}{l}\text { Athletic } \\
\text { trainers }\end{array}$ & $<20$ & 1 (1994) & 273 & 16 & 29 & & & $\begin{array}{l}\text { Total: } \\
135.6 \\
\text { FP: } 89.7 \\
\text { RR: } 294.1\end{array}$ & $\begin{array}{l}\text { Total: } \\
26.4 \\
\text { FP: } 17 \\
\text { RR: } 64.5\end{array}$ \\
\hline [23] & $\mathrm{P}$ & MDs & $\begin{array}{l}\text { JV: } 15-18 \\
\text { V: } 16-19\end{array}$ & $1(1994-1995)$ & $\begin{array}{l}\text { JV: } 39 \\
\text { V: } 47\end{array}$ & $\begin{array}{l}J V: 3 \\
V: 3\end{array}$ & $\begin{array}{l}\text { JV: } 10 \\
\text { V: } 17\end{array}$ & & & $\begin{array}{l}\text { JV: } 30.3 \\
\text { V: } 49.7\end{array}$ & \\
\hline [24] & $\mathrm{R}$ & Quest. & $14-18$ & $2(1982-1984)$ & 480 & 12 & $\begin{array}{l}\text { Shoulder } \\
\text { only } \\
45\end{array}$ & & 9.4 & & \\
\hline [25] & $\mathrm{P}$ & $\begin{array}{r}\text { Coaches/ } \\
\text { trainers }\end{array}$ & $?$ & $1(1974-1975)$ & 207 & 11 & 41 & & & 62.1 & \\
\hline
\end{tabular}


Table 2. (continued)

\begin{tabular}{|c|c|c|c|c|c|c|c|c|c|c|c|}
\hline \multirow[t]{2}{*}{ Level/Study } & \multirow{2}{*}{$\begin{array}{l}\text { Design } \\
\mathrm{P} / \mathrm{R}\end{array}$} & \multirow{2}{*}{$\begin{array}{l}\text { Injury } \\
\text { collection } \\
\text { (source) }\end{array}$} & \multirow{2}{*}{$\begin{array}{l}\text { Age } \\
\text { (years) }\end{array}$} & \multirow{2}{*}{$\begin{array}{l}\text { Duration of } \\
\text { study(number } \\
\text { of seasons } \\
\text { and year) }\end{array}$} & \multirow{2}{*}{$\begin{array}{l}\text { Sample } \\
\text { number of } \\
\text { subjects }\end{array}$} & \multirow{2}{*}{$\begin{array}{l}\text { Sample } \\
\text { number } \\
\text { of teams }\end{array}$} & \multirow{2}{*}{$\begin{array}{l}\text { Number of } \\
\text { injuries }\end{array}$} & \multicolumn{4}{|l|}{ Injury rate } \\
\hline & & & & & & & & $\begin{array}{l}\text { injuries } \\
\text { per game }\end{array}$ & $\begin{array}{l}\text { injuries per } \\
100 \text { players }\end{array}$ & $\begin{array}{l}\text { injuries } \\
\text { per } 1,000 \mathrm{~h}\end{array}$ & $\begin{array}{l}\text { injuries per } \\
1,000 \mathrm{~A}-\mathrm{E}\end{array}$ \\
\hline $\begin{array}{l}\text { Minor } \\
{[26]}\end{array}$ & $\mathrm{R}$ & $\begin{array}{l}\text { Insurance } \\
\text { and Federal } \\
\text { Stats }\end{array}$ & $14-20$ & 1987-1989 & 29,911 & $?$ & 1,570 & & & 86 & \\
\hline [20] & $\mathrm{P}$ & $\begin{array}{l}\text { Emerg/ } \\
\text { Quest. }\end{array}$ & 7-18 & 1995-1996 & 103 & $\mathrm{n} / \mathrm{a}$ & 113 & & & & \\
\hline [15] & $\mathrm{P}$ & $\begin{array}{l}\text { Managers/ } \\
\text { coaches }\end{array}$ & $9-15$ & $1(1990-1991)$ & 150 & 9 & 52 & & 35 & & \\
\hline [12] & $P$ & Quest. & 9-18 & $1(1990-1991)$ & 1,437 & 54 & 128 & & $\begin{array}{l}<12 \text { years: } \\
0.88 \\
12-15 \text { years: } \\
12.4 \\
15-18 \text { years: } \\
25.3\end{array}$ & & \\
\hline [3] & $P$ & MD & 9-14 & 1 (1993-1994) & 66 & 4 & 14 & & & $\begin{array}{l}9-10 \\
\text { years: } 1.0 \\
11-12 \\
\text { years: } 1.8 \\
13-14 \\
\text { years: } 4.3\end{array}$ & \\
\hline [14] & $P$ & Survey & $12-13$ & $1(1985-1986)$ & 279 & $\begin{array}{l}\text { BC } \\
\text { (AA): } 6 \\
\text { BC } \\
\text { (CC): } 22 \\
\text { NBC } \\
\text { (CC): } 21\end{array}$ & $\begin{array}{l}\mathrm{BC} \\
(\mathrm{AA}): 19 \\
\mathrm{BC} \\
(\mathrm{CC}): 26 \\
\mathrm{NBC} \\
\text { (CC): } 7\end{array}$ & & & & \\
\hline [19] & $\mathrm{P}$ & Survey & $14-15$ & $\begin{array}{l}2 \\
(1987-1989)\end{array}$ & $?$ & $\begin{array}{l}\text { Minor: } 37 \\
\text { Major: } 44\end{array}$ & $\begin{array}{l}\text { Minor: } 632 \\
\text { Major: } 132\end{array}$ & $\begin{array}{l}\text { Minor: } 2.08 \\
\text { Major: } 0.12\end{array}$ & & & \\
\hline [11] & $\mathrm{R}$ & $\begin{array}{l}\text { Patient } \\
\text { records }\end{array}$ & $6-15$ & $\begin{array}{l}3 \\
(1980-1982)\end{array}$ & $\begin{array}{l}1,124 \text { sport- } \\
\text { related } \\
\text { injuries }\end{array}$ & $\begin{array}{l}\text { N/A } \\
\text { (emergency } \\
\text { patients) }\end{array}$ & 290 (26\%) & & & & \\
\hline
\end{tabular}




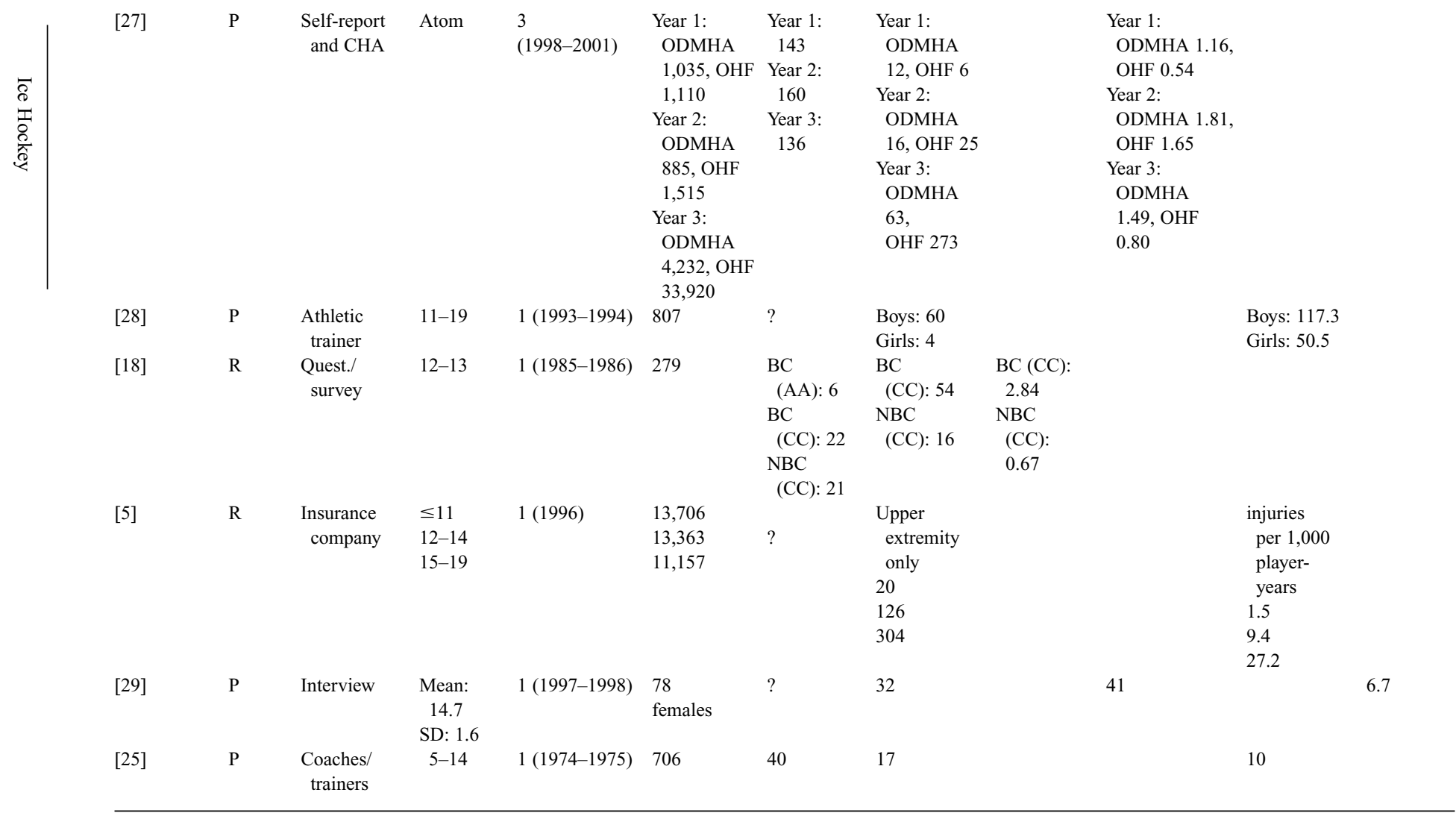

LTS $=$ Larger than standard ice surface $\left(>17,000 \mathrm{ft}^{2}\right) ; \mathrm{S}=$ standard ice surface $\left(200 \times 85 \mathrm{ft}-17,000 \mathrm{ft}^{2}\right) ;$ STS $=<$ standard ice surface $\left(<17,000 \mathrm{ft}^{2}\right) ;$ SD $=$ standard deviation.

Minor $=$ An injury as the result of a blow that damages the integrity of human tissue and causes a temporary incapacity (a shift missed) on the part of the player injured.

Major $=$ An injury as the result of a blow that damages the integrity of human tissue creating a state of incapacity that prevents the person from playing or practicing during a certain period of time.

$\mathrm{A}-\mathrm{E}=$ athlete-exposures; $\mathrm{P}=$ prospective; $\mathrm{R}=$ retrospective; $\mathrm{V}=$ varsity; $\mathrm{JV}=$ junior varsity; $\mathrm{NFS}=$ no face shield; $\mathrm{HS}=$ half shield; $\mathrm{FS}=$ full shield; $\mathrm{FP}=$ fair play rules; $\mathrm{RR}=$ regular rules; $\mathrm{BC}(\mathrm{AA})=$ body checking, level $\mathrm{AA} ; \mathrm{BC}(\mathrm{CC})=$ body checking, level $\mathrm{CC} ; \mathrm{NBC}(\mathrm{CC})=$ no body checking, level $\mathrm{CC}$. 
injury rates (e.g., incidence: injuries per 1,000 athlete-exposures, injuries per 1,000 player-hours, prevalence: injuries per 100 players), and varying definitions of injury (time loss vs. no time loss vs. specific anatomical injuries). Retrospective studies identified injury prevalence within a specific team or league and were less accurate in identifying the true population at risk of injury.

\section{Injury Characteristics}

\section{Injury Location}

The reported hockey-related anatomic injury locations across the entire body are shown in Table $3[2,3,5,7,10-13,15,17,18,22,23,25,28,29]$. Players competing at the Minor hockey level sustained most of their injuries to the upper extremity (23-55\%; shoulder, $11.6-22 \%$; arm, 3.9-23\%), followed by the spine/trunk (13-32.8\%; chest/ribs, 7.7-14\%; neck, 7-9.7\%; back, 7-9.6\%), head (7-30\%), and lower extremity (21-27\%; knee, 7-9.6\%; leg, 3.9-27\%; thigh, 3.9-7\%). At the High School level, the head was the primary anatomic area injured, accounting for between $14.8 \%$ and $31 \%$ of the total injuries sustained. The lower extremity was the next most common injured part of the body (20.6-37\%; knee, 6.9-14.8\%; thigh, 6.9-11.1\%), followed by the upper extremity (3.4-29\%; shoulder, 3.4-16\%;), and spine/trunk (7.4-17.2\%; chest/ribs, 6.9-7.4\%; back, 5-6.9\%). At the Junior level of competition, the lower extremity was the primary region injured (24.9-33.7\%; pelvis/hips, $4.2-14 \%$; knee, $4.2-13.3 \%$; thigh, $4-12.8 \%$ ), followed by the upper extremity (9.6-35.4\%; shoulder, 4.8-20\%; hand/fingers, 5-16.7\%), the head (14.4-28\%; face, 9.6-29.2\%), and the spine/trunk (6-14.9\%; neck, 1-8.5\%; back, $2.1-8.3 \%$ ).

There was a dramatic decrease in the proportion of head and neck injury insurance claims by 8-16-year-old United States amateur hockey players from $45 \%$ during the $1975-1976$ season to $36 \%$ the season after the American Society of Testing Materials standard, 'Eye and Face Protective Equipment for Hockey Players' (F513-77), was passed [30]. The American Society of Testing Materials is a voluntary organization which develops consensus standards for thousands of materials, systems, and products which are used in society - a subcommittee representing ice hockey was asked by the Amateur Hockey Association of the United States to develop a standard for facial protection [30]. Claims dropped to $31 \%$ during the 1977-1978 season and remained at that level through to the 1983-1984 season. In addition, dental claims dropped greater than 50\% from 1975 to 1984 [30]. Kvist et al. [11] studied sport-related injury profiles of children aged 6-15 years treated in the Turku University Central Hospital Casualty Department from 1980 to 1982 . Twenty-six percent $(290 / 1,124)$ of the 
Table 3. A percent comparison of injury location among pediatric ice hockey players

\begin{tabular}{|c|c|c|c|c|c|c|c|c|c|c|c|c|c|c|c|c|c|}
\hline \multirow{3}{*}{$\begin{array}{l}\text { Injuries } \\
\begin{array}{r}\text { Total no. } \\
\text { injuries }\end{array}\end{array}$} & \multicolumn{4}{|c|}{ Junior (\%) } & \multicolumn{4}{|c|}{ High School (\%) } & \multicolumn{9}{|c|}{ Minor (\%) } \\
\hline & [2] & [13] & {$[10]$} & [22] & [7] & {$[17]$} & {$[25]$} & [23] & {$[28]$} & {$[15]$} & [12] & [3] & [11] & $\begin{array}{l}{[18]} \\
\text { BC (CC): } 54\end{array}$ & $\begin{array}{l}\text { [5] } \\
\text { (upper } \\
\text { extremity } \\
\text { only) }\end{array}$ & $\begin{array}{l}{[29]} \\
32\end{array}$ & {$[25]$} \\
\hline & 142 & 83 & 74 & $\begin{array}{l}\text { (head, neck, } \\
\text { facial } \\
\text { only) } 113\end{array}$ & $\begin{array}{l}75 / 100 \\
\text { players }\end{array}$ & 29 & 41 & 27 & $\begin{array}{l}\text { Boys: } 60 \\
\text { Girls: } 4\end{array}$ & 52 & 128 & 14 & 290 & NBC (CC): 16 & $\begin{array}{l}\leq 11: 20 \\
12-14: 126 \\
15-19: 304\end{array}$ & $\begin{array}{l}\text { (females } \\
\text { only) }\end{array}$ & \\
\hline Head & 2 & & & & 19 & & 68.2 & 14.8 & & 9.6 & 10 & 7 & & $\begin{array}{l}\text { BC (CC): } 16.7 \\
\text { NBC (CC): } 12.5\end{array}$ & & $\begin{array}{l}6.3 \\
\text { (including } \\
\text { neck) }\end{array}$ & 58.7 \\
\hline Face & 26 & 9.6 & $\begin{array}{r}\text { Fwd: } 23.4, \\
\text { Def: } 29.2\end{array}$ & 58 & & 6.9 & & & $\begin{array}{l}\text { Head and } \\
\text { neck }\end{array}$ & 3.9 & & & & & & & \\
\hline Teeth & & 4.8 & & 14 & & 0 & & & Boys: 30 & 0 & 2.3 & & 10 & & & & \\
\hline Concussion & & & 1.4 & 13 & 12 & 13.8 & & & Girls: 0 & & & & & & & & \\
\hline Eye & & 0 & 0 & 12 & & 0 & 2.4 & & & 0 & & & & & & & 5.9 \\
\hline Spine/Trunk & & & & & & & & 7.4 & & & 13 & & & $\begin{array}{l}\text { BC (CC): } 24.1 \\
\text { NBC (CC): } 31.3\end{array}$ & & 31.3 & \\
\hline Neck & 1 & & $\begin{array}{r}\text { Fwd: } 8.5, \\
\text { Def: } 4.2\end{array}$ & 0.9 & 3 & 3.4 & & & & 9.7 & & 7 & & $\begin{array}{l}\text { BC (CC): } 16.7 \\
\text { NBC (CC): } 6.25\end{array}$ & & & \\
\hline Upper back & & 4.8 & Back & & Back & Back & Back & & & Back & & & & & & & \\
\hline Lower back & 6 & & $\begin{array}{l}\text { Fwd: } 2.1, \\
\text { Def: } 8.3\end{array}$ & & 5 & 6.9 & 4.9 & & & 9.6 & & 7 & & & & & \\
\hline Chest/Ribs & 2 & 1.2 & $\begin{array}{l}\text { Fwd: } 4.3 \text {, } \\
\text { Def: } 0\end{array}$ & & 7 & 6.9 & & 7.4 & & 7.7 & & 14 & & & & & \\
\hline Abdomen & 1 & 0 & 0 & & 2 & 0 & & & & 5.8 & & & & & & & \\
\hline $\begin{array}{l}\text { Upper } \\
\text { extremity }\end{array}$ & & & & & & & & & & & 55 & & & $\begin{array}{l}\text { BC (CC): } 16.7 \\
\text { NBC (CC): } 12.5\end{array}$ & & 21.9 & \\
\hline Shoulder & 20 & 4.8 & $\begin{array}{r}\text { Fwd: } 12.8, \\
\text { Def: } 12.5\end{array}$ & & 16 & 3.4 & 2.4 & 11.1 & & 11.6 & & 22 & & & $\begin{array}{l}\leq 11: 0.5 \\
12-14: 11 \\
15-19: 35\end{array}$ & & 5.9 \\
\hline Arm & & & $\begin{array}{l}\text { Fwd: } 2.1 \text {, } \\
\text { Def: } 0\end{array}$ & & 13 & 0 & & & $\begin{array}{l}\text { Boys: } 23 \\
\text { Girls: } 0\end{array}$ & 3.9 & & 22 & & & & & \\
\hline
\end{tabular}


Table 3 (continued)

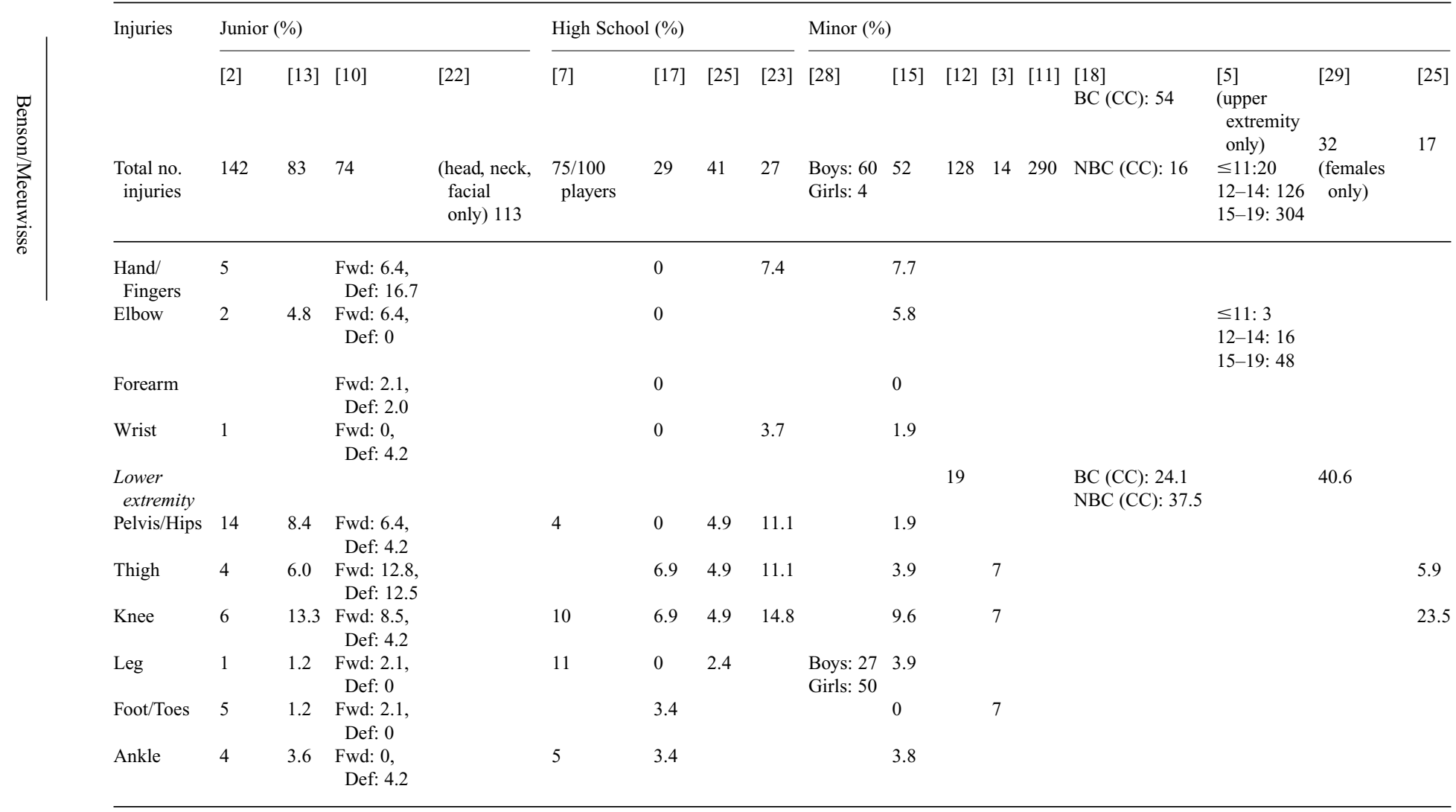

$\mathrm{BC}(\mathrm{CC})=$ Body checking, level CC; $\mathrm{NBC}(\mathrm{CC})=$ no body checking, level CC 
total reported sport-related injuries were sustained in ice hockey (boys: $24.9 \%$; girls: $1 \%$ ). Thirty-four percent of the hockey-related injuries were to the head and neck, and approximately two-thirds (65\%) of the total dental injuries and $3.7 \%$ of fractures sustained by boys occurred in ice hockey. Bjorkenheim et al. [12] studied the risk and type of injuries sustained by 1437 players (aged 9-18 years) who were required to wear full facial protection in an organized junior league in Helsinki. Only $1 \%$ of the 682 ice hockey players aged 9-12 years were injured, compared with $14 \%$ of the 534 players aged $12-15$, and $23 \%$ of the 221 players aged 15-18 years [12]. These results suggest that teenagers were the most vulnerable to hockey-related injuries caused by direct trauma. Of note, $32 \%$ of the total injuries were caused by an illegal play. Park and Castaldi [13] studied the types and frequency of game injuries sustained by players aged 15-19 years from one Junior 'B' hockey team during the 1977-1978 season. Facial injuries were the most frequent type (22.6\%), followed by knee injuries $(13.3 \%)$, hip and forearm/arm injuries (7.2\% each), and thigh and groin injuries (6.0\% each), respectively. Pinto et al. [10] studied injuries sustained by 16-20-year-old players from one Junior ' $\mathrm{A}$ ' hockey team over the course of one season. The most common site of injury was the face, accounting for $24.3 \%$ of the total injuries. The shoulder and hand/fingers were the next most common injured area (12.2\% each), followed by the knee and thigh $(9.5 \%$ each).

\section{Situational}

Table 4 highlights injury rates reported during practices and games for the studies selected for review [2, 3, 7, 10, 12, 15, 20, 21, 23, 24, 29]. An overwhelming majority of injuries were sustained during games compared with practices. Pinto et al. [10] studied injuries sustained by 16-20-year-old players from one Junior ' $\mathrm{A}$ ' hockey team over the course of a season. The injury rate during games was more than 20 times the rate during practices, and exhibition and preseason games had an injury rate greater than 3 times that of regular season and postseason games. Stuart and Smith [2] studied the incidence and types of injuries sustained during practices and games for one US Junior ' $A$ ' hockey team over 3 consecutive seasons. Players were 25 times more likely to be injured during games than practices. Overall, the percent of total injuries sustained during games ranged from 58 to 96.3 , with a rate between 4.63 injuries per 1,000 hours and 143 injuries per 1,000 hours. In practices, injury rates ranged from zero to 23 injuries per 1,000 hours, with injuries accounting for between 3.7 and $37 \%$ of the total reported injuries.

\section{Action or Activity}

Table 5 shows the mechanism of injury for the studies selected for review $[2,3,5,7,10,12-14,15-25,28,29,31-33]$. In Junior hockey, the primary 
Table 4. A comparison of injury rates in practices versus games among pediatric ice hockey players

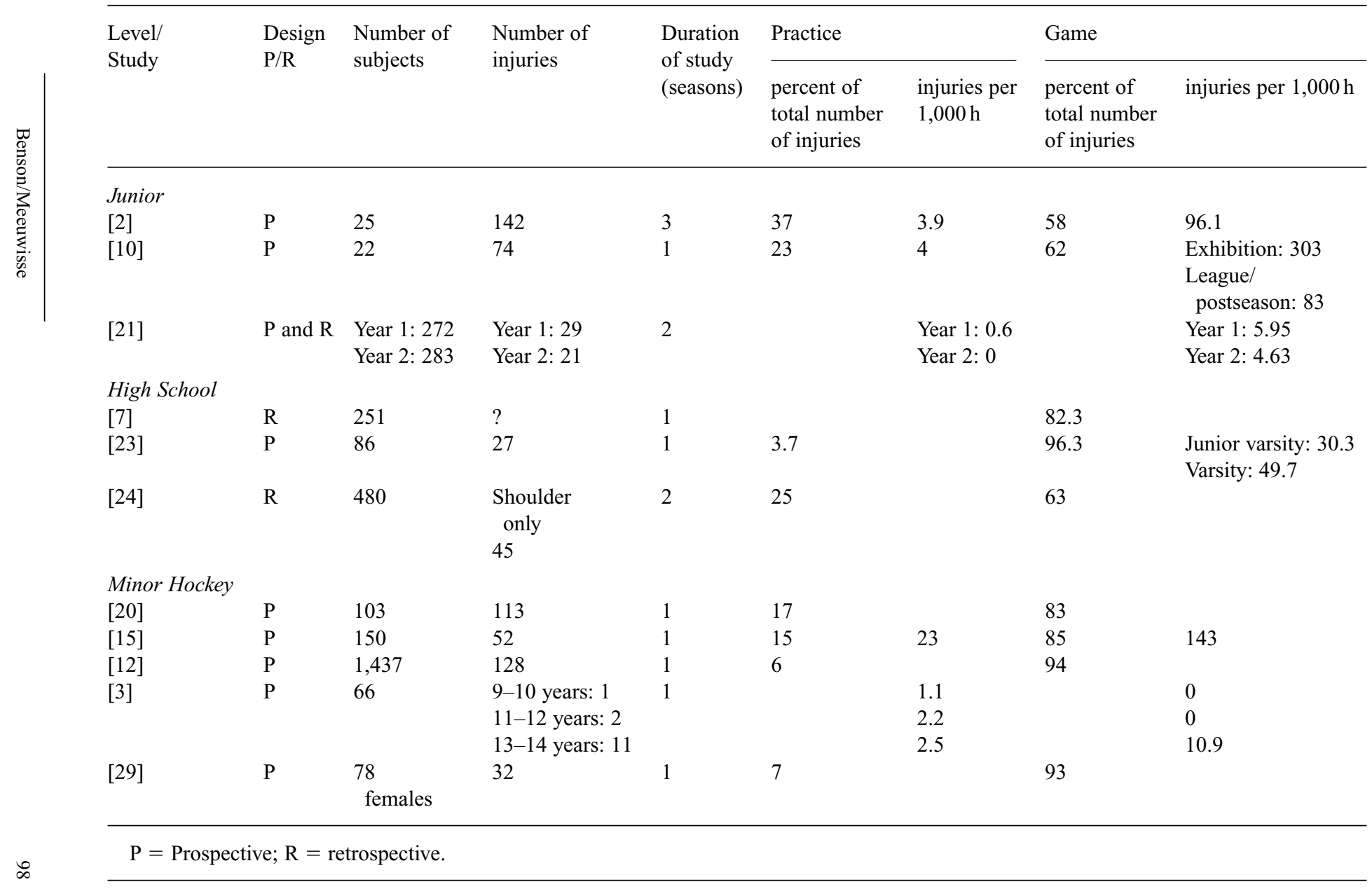


Table 5. A percent comparison of mechanism of injury among pediatric ice hockey players

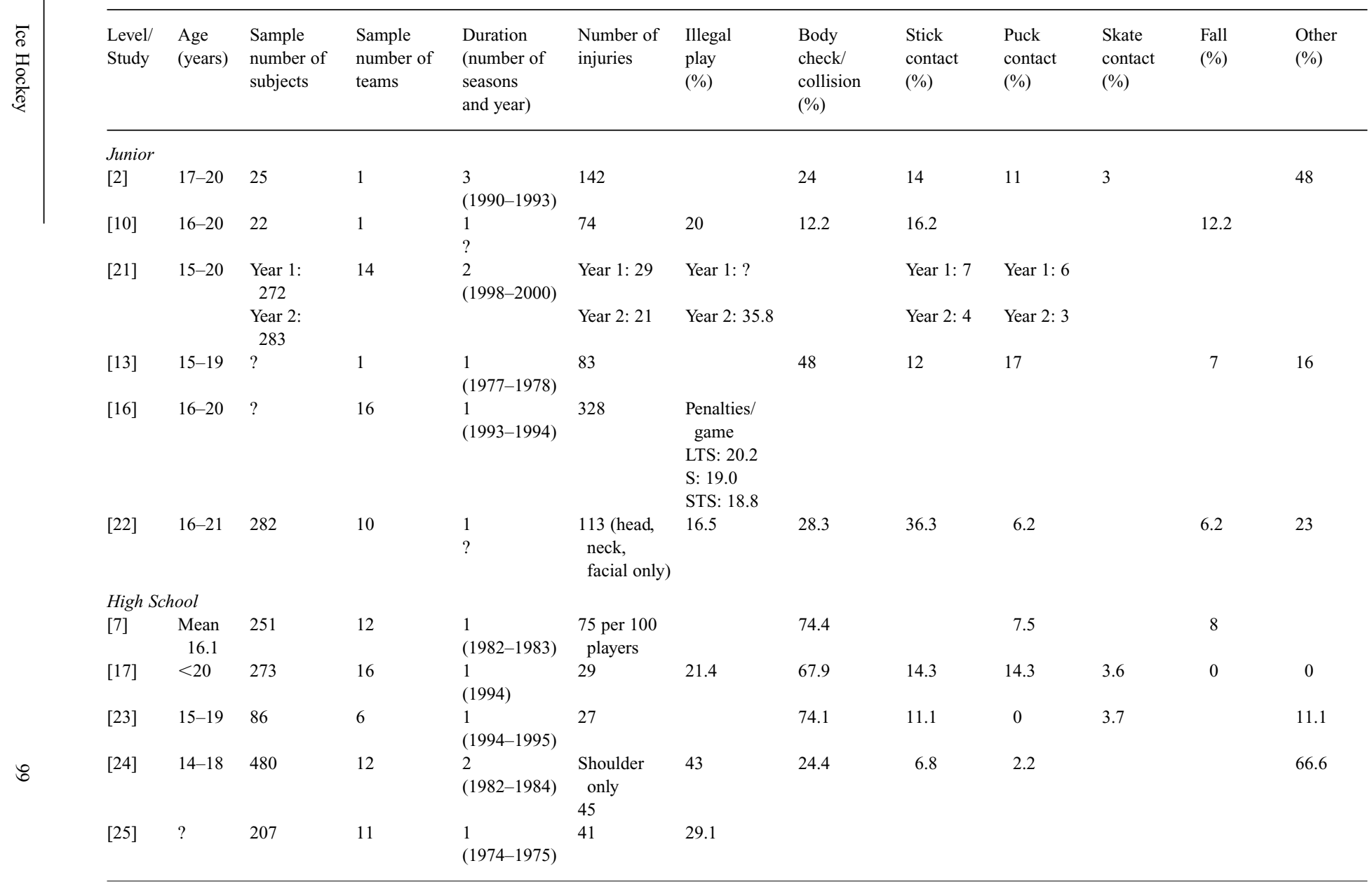




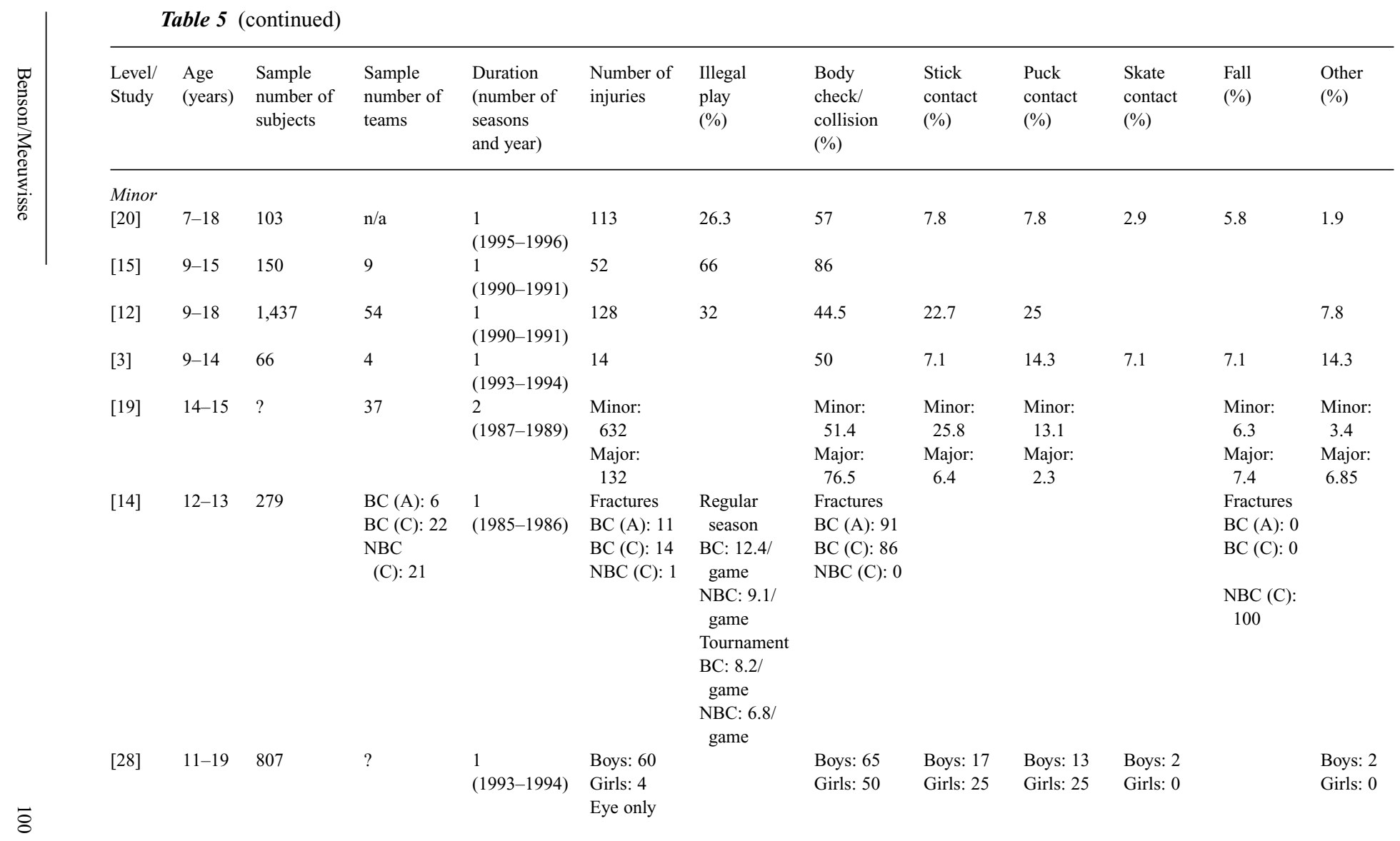




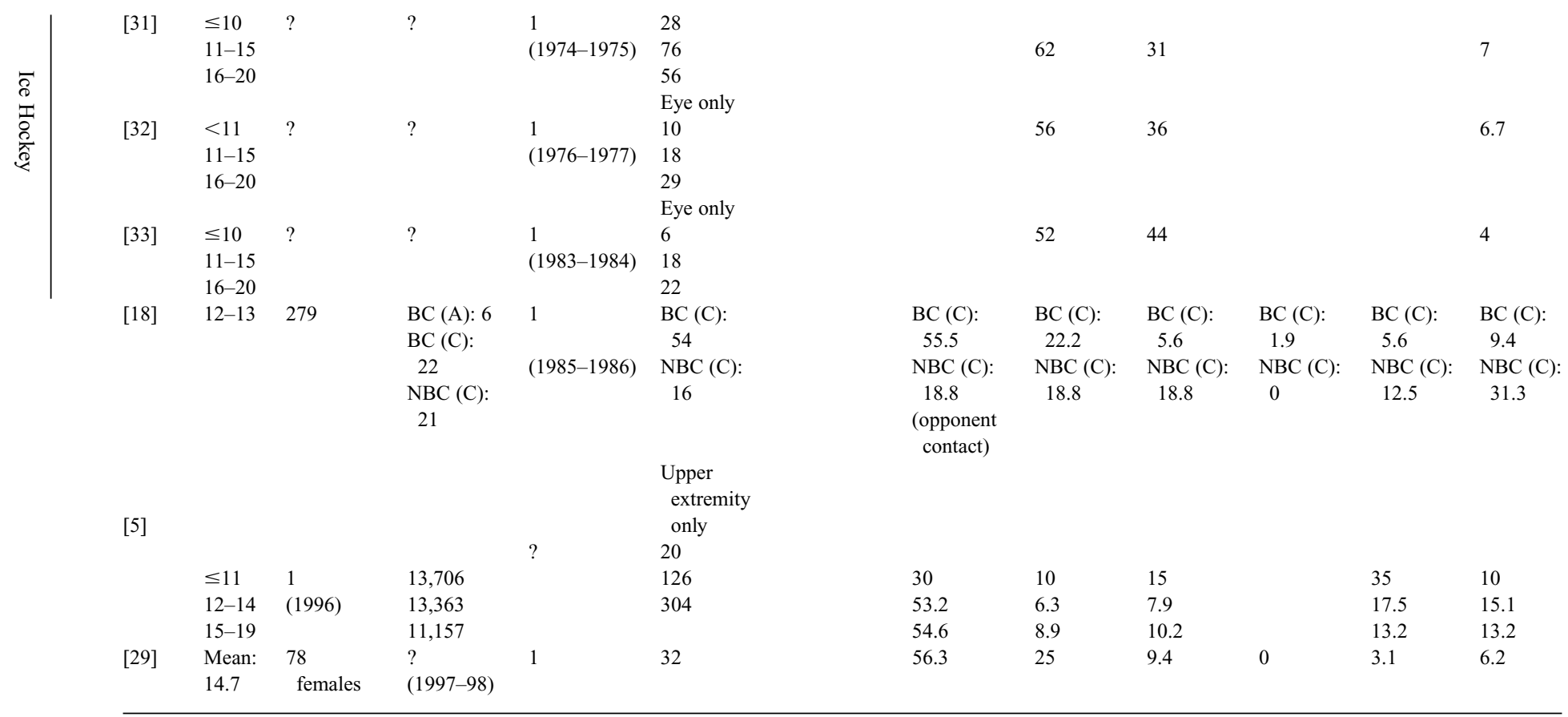

LTS $=$ Larger than standard ice surface $\left(>17,000 \mathrm{ft}^{2}\right) ; \mathrm{S}=$ standard ice surface $\left(200 \times 85 \mathrm{ft}=17,000 \mathrm{ft}^{2}\right)$; STS $=$ smaller than standard ice surface $\left(<17,000 \mathrm{ft}^{2}\right)$. $\mathrm{BC}(\mathrm{A})=$ Body checking, level AA; $\mathrm{BC}(\mathrm{C})=$ body checking, level $\mathrm{CC} ; \mathrm{NBC}(\mathrm{C})=$ no body checking, level CC.

Note: If cell is blank, specific mechanism was not reported. 
mechanism of injury was body checking (12.2-48\%), followed by puck contact (3-17\%), and stick contact (4-16.2\%). Illegal play reportedly caused between 16.5 and $35.8 \%$ of the total injuries at this level of competition. In High School hockey, body checking was again the most common cause of injury ranging from $67.9-74.1 \%$ of the total reported injuries. Stick contact was the second most common (11.1-14.3\%), followed by puck contact (0-14.3\%). Illegal play reportedly caused between 21.4 and $29.1 \%$ of the injuries. Similarly, body checking was the predominant mechanism of injury at the Minor hockey level (50-86\%), followed by stick contact (6.4-25.8\%), and puck contact (2.3-14.3\%). Illegal play was involved in $26.3-66 \%$ of injuries.

\section{Injury Severity}

\section{Injury Types}

Table 6 shows a percent comparison of the different types of injuries sustained by pediatric ice hockey players, separated by level of competition $[2,3,5,7,10-15,17-20,22-25,28,29]$. In Junior hockey, the three most common reported types of injuries were sprains/strains (20.5-41\%), contusions (18-45.8\%), and lacerations (9.6-24\%). Similarly, the most frequent types of injuries in High School hockey were contusions (29-58.6\%), sprains/strains (6.8-37\%), lacerations (10.3-13\%), and concussions (3.7$13.8 \%)$. The most common injury types sustained in Minor hockey were contusions (13-64.9\%), sprains/strains (10-32.2\%), fractures (2.4-54\%), concussions (5-43\%), and lacerations (5.6-19\%). Regnier et al. [14] showed that the rate of fractures was 12 times greater for Pee-Wee level players competing in a league that allowed body checking compared with one that did not allow any body checking.

\section{Catastrophic Injury}

Table 7 highlights catastrophic injury rates among pediatric ice hockey players [30-34]. Catastrophic injuries were defined as those injuries that caused death or permanent disability. In 1973, a Canadian ophthalmologist, Dr. Tom Pashby, investigated ocular injuries among Canadian amateur hockey players and reported that 287 hockey-related eye injuries were treated by members of the Canadian Ophthalmologic Society during one season, 20 of which resulted in blindness [31]. Similarly, during the 1974-1975 Canadian amateur season, 257 ocular injuries were treated with 43 instances of legal blindness [32]. In the United States, the Consumer Products Safety Commission reported an increase in amateur ice hockey injuries from 30,000 to 50,000 between 1973 and 1975, two-thirds of which involved the head/face and 5-9\% the eye [35]. Results 
Table 6. A percent comparison of injury types among pediatric ice hockey players

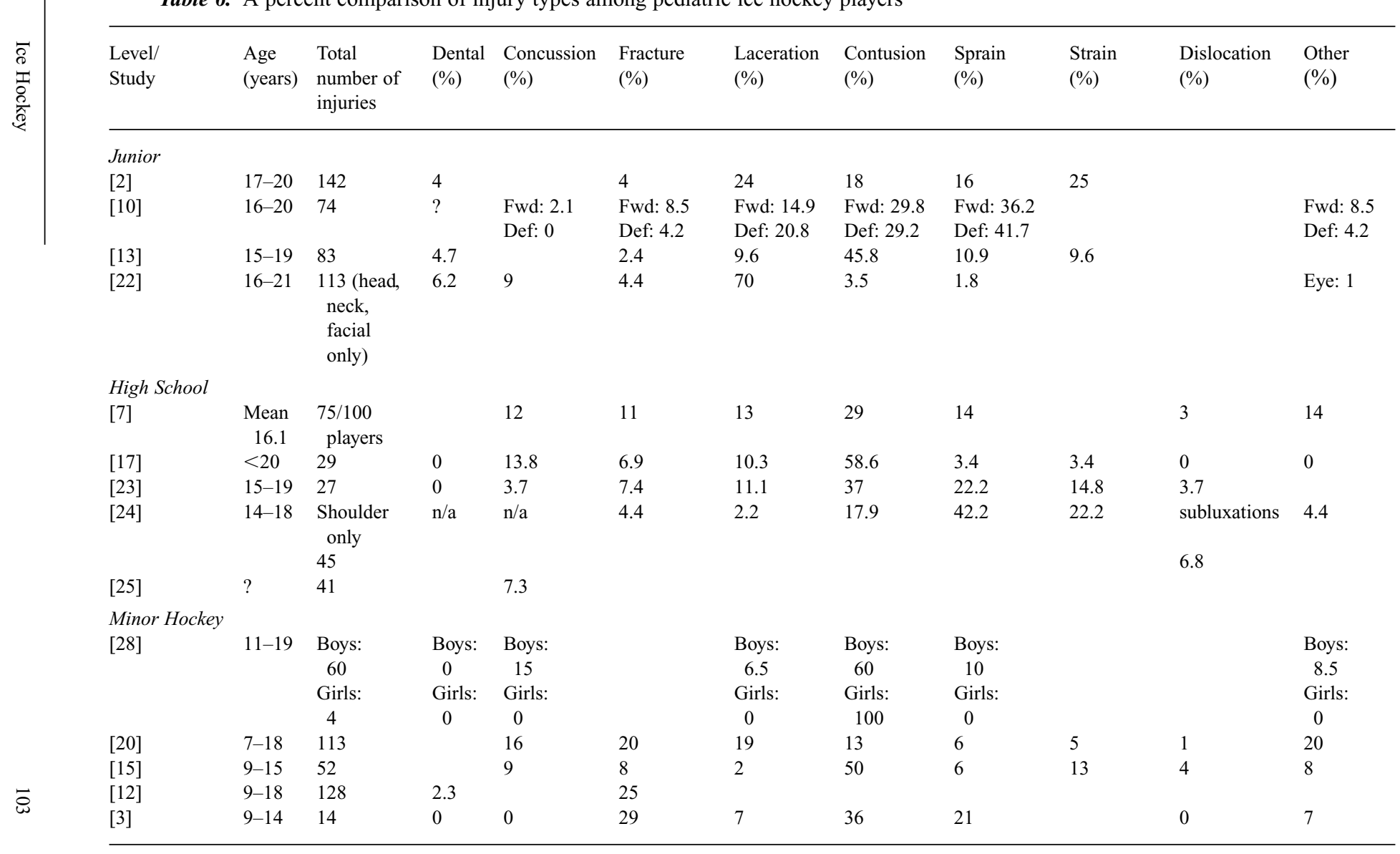


Table 6 (continued)

\begin{tabular}{|c|c|c|c|c|c|c|c|c|c|c|c|}
\hline $\begin{array}{l}\text { Level/ } \\
\text { Study }\end{array}$ & $\begin{array}{l}\text { Age } \\
\text { (years) }\end{array}$ & $\begin{array}{l}\text { Total } \\
\text { number of } \\
\text { injuries }\end{array}$ & $\begin{array}{l}\text { Dental } \\
(\%)\end{array}$ & $\begin{array}{l}\text { Concussion } \\
(\%)\end{array}$ & $\begin{array}{l}\text { Fracture } \\
(\%)\end{array}$ & $\begin{array}{l}\text { Laceration } \\
(\%)\end{array}$ & $\begin{array}{l}\text { Contusion } \\
(\%)\end{array}$ & $\begin{array}{l}\text { Sprain } \\
(\%)\end{array}$ & $\begin{array}{l}\text { Strain } \\
(\%)\end{array}$ & $\begin{array}{l}\text { Dislocation } \\
(\%)\end{array}$ & $\begin{array}{l}\text { Other } \\
(\%)\end{array}$ \\
\hline$[14]$ & $12-13$ & $\begin{array}{l}\text { BC (AA): } \\
19 \\
\text { BC (CC): } \\
26 \\
\text { NBC (CC): } \\
7\end{array}$ & & $\begin{array}{l}\text { BC (AA): } \\
5 \\
\text { BC (CC): } \\
15 \\
\text { NBC (CC): } \\
43\end{array}$ & $\begin{array}{l}\text { BC (AA): } \\
58 \\
\text { BC (CC): } \\
54 \\
\text { NBC (CC): } \\
14\end{array}$ & & & $\begin{array}{l}\mathrm{BC}(\mathrm{AA}): \\
21 \\
\mathrm{BC}(\mathrm{CC}): \\
23 \\
\mathrm{NBC}(\mathrm{CC}): \\
29\end{array}$ & & $\begin{array}{l}\text { BC (AA): } \\
16 \\
\text { BC (CC): } \\
8 \\
\text { NBC (CC): } \\
14\end{array}$ & \\
\hline \multirow{3}{*}{$\begin{array}{l}{[11]} \\
{[19]}\end{array}$} & $6-15$ & 290 & 10 & & Boys: 2.4 & & & & & & \\
\hline & $14-15$ & $\begin{array}{l}\text { Minor: } \\
632\end{array}$ & & Minor: ? & Minor: ? & $\begin{array}{l}\text { Minor: } \\
5.6\end{array}$ & $\begin{array}{l}\text { Minor: } \\
64.9\end{array}$ & Minor: ? & & Minor: ? & $\begin{array}{c}\text { Minor: } \\
29.7\end{array}$ \\
\hline & & $\begin{array}{c}\text { Major: } \\
132\end{array}$ & & $\begin{array}{c}\text { Major: } \\
15.6\end{array}$ & $\begin{array}{c}\text { Major: } \\
28.6\end{array}$ & Major: ? & Major: ? & $\begin{array}{l}\text { Major: } \\
32.2\end{array}$ & & $\begin{array}{l}\text { Major: } \\
8.6\end{array}$ & $\begin{array}{c}\text { Major: } \\
14.1\end{array}$ \\
\hline \multirow[t]{2}{*}{ [18] } & $12-13$ & $\begin{array}{l}\mathrm{BC}(\mathrm{CC}): \\
54\end{array}$ & & $\begin{array}{l}\mathrm{BC}(\mathrm{CC}): \\
1.9\end{array}$ & $\begin{array}{l}\text { BC: } \\
n=25\end{array}$ & $\begin{array}{l}\mathrm{BC}(\mathrm{CC}): \\
1.9\end{array}$ & $\begin{array}{l}\text { BC (CC): } \\
72.2\end{array}$ & & $\begin{array}{l}\mathrm{BC}(\mathrm{CC}): \\
3.7\end{array}$ & $\begin{array}{l}\mathrm{BC}: \\
\mathrm{n}=5\end{array}$ & $\begin{array}{l}\text { BC (CC): } \\
20.4\end{array}$ \\
\hline & & $\begin{array}{l}\text { NBC }(C C): \\
16\end{array}$ & & $\begin{array}{l}\mathrm{NBC}(\mathrm{CC}): \\
6.3\end{array}$ & $\begin{array}{l}\text { NBC: } \\
n=1\end{array}$ & $\begin{array}{l}\text { NBC }(\mathrm{CC}) \\
0\end{array}$ & $\begin{array}{l}\text { NBC }(C C): \\
68.8\end{array}$ & & $\begin{array}{l}\text { NBC (CC): } \\
6.3\end{array}$ & $\begin{array}{l}\text { NBC: } \\
n=1\end{array}$ & $\begin{array}{l}\text { NBC (CC): } \\
18.8\end{array}$ \\
\hline \multirow[t]{4}{*}{ [5] } & & $\begin{array}{l}\text { Upper } \\
\text { extremity }\end{array}$ & & & & & & & & & \\
\hline & $\leq 11$ & 20 & & & 4 & & & & & & \\
\hline & $12-14$ & 126 & & & 22 & & & & & & \\
\hline & $15-19$ & 304 & & & 44 & & & & & & \\
\hline [29] & $\begin{array}{c}\text { Mean: } \\
14.7\end{array}$ & $\begin{array}{l}32 \\
\text { (females } \\
\text { only) }\end{array}$ & 0 & 3.1 & 3.1 & 0 & 50 & 37.5 & & 0 & 6.3 \\
\hline [25] & $5-14$ & 17 & & 11.7 & & & & & & & \\
\hline
\end{tabular}

$\mathrm{BC}(\mathrm{AA})=$ Body checking, level AA; $\mathrm{BC}(\mathrm{CC})=$ body checking, level CC; $\mathrm{NBC}(\mathrm{CC})=$ no body checking, level CC.

Minor $=$ An injury as the result of a blow that damages the integrity of human tissue and causes a temporary incapacity (a shift missed) on the part of the player injured.

Major $=$ An injury as the result of a blow that damages the integrity of human tissue creating a state of incapacity that prevents the person from playing or practicing during a certain period of time.

Note: If cell is blank, either no injury occurred or data was not reported. 
Table 7. A comparison of catastrophic injury rates among pediatric ice hockey players

\begin{tabular}{|c|c|c|c|c|c|c|c|}
\hline Study & $\begin{array}{l}\text { Number of } \\
\text { subjects }\end{array}$ & $\begin{array}{l}\text { Age } \\
\text { (years) }\end{array}$ & $\begin{array}{l}\text { Duration } \\
\text { (years) }\end{array}$ & $\begin{array}{l}\text { Injury } \\
\text { type }\end{array}$ & Condition & $\begin{array}{l}\text { Absolute } \\
\text { number }\end{array}$ & $\begin{array}{l}\text { Rate } \\
\text { Number per } \\
1,000 \text { athletes }\end{array}$ \\
\hline [30] & $\sim 700,000$ & $5-14$ & 1973-1980 & $?$ & Death & & 0.0029 \\
\hline \multirow[t]{4}{*}{ [34] } & \multirow[t]{4}{*}{$147 / 241$} & \multirow[t]{4}{*}{$11-20$} & \multirow{4}{*}{$\begin{array}{l}\text { Case-series } \\
\text { 1966-1993 }\end{array}$} & \multirow{4}{*}{$\begin{array}{l}\text { Cervical } \\
\text { spine injury }\end{array}$} & Fatality & $8 / 241$ & \\
\hline & & & & & Permanent & $108 / 207$ & \\
\hline & & & & & injury & & \\
\hline & & & & & $\begin{array}{l}\text { Complete } \\
\text { cord injury }\end{array}$ & $52 / 207$ & \\
\hline \multirow[t]{3}{*}{ [31] } & \multirow[t]{3}{*}{$?$} & $\leq 10$ & \multirow[t]{3}{*}{ 1974-1975 } & \multirow[t]{3}{*}{ Eye injury } & (blind) & 28 , blind: 5 & \\
\hline & & $11-15$ & & & & 76, blind: 6 & \\
\hline & & $16-20$ & & & & 56, blind: 9 & \\
\hline \multirow[t]{3}{*}{ [32] } & \multirow[t]{3}{*}{$?$} & $<11$ & \multirow[t]{3}{*}{ 1976-1977 } & \multirow[t]{3}{*}{ Eye injury } & \multirow[t]{3}{*}{ (blind) } & 10, blind: 0 & \\
\hline & & $11-15$ & & & & 18, blind: 1 & \\
\hline & & $16-20$ & & & & 29 , blind: 5 & \\
\hline \multirow[t]{3}{*}{ [33] } & \multirow[t]{3}{*}{$?$} & $\leq 10$ & \multirow[t]{3}{*}{ 1983-1984 } & \multirow[t]{3}{*}{ Eye injury } & \multirow[t]{3}{*}{ (blind) } & 6, blind: 0 & \\
\hline & & $11-15$ & & & & 18 , blind: 0 & \\
\hline & & $16-20$ & & & & 22, blind: 0 & \\
\hline
\end{tabular}

from studies such as these were instrumental in encouraging hockey administrators to implement mandatory full face shield rules in 1976 for all United States players under the age of 20, and in 1977-1978 for all United States College players [36]. The Canadian Amateur Hockey Association followed this initiative and mandated full facial protection in 1978 for all athletes under its jurisdiction [36].

Research conducted after the implementation of these rules showed a marked reduction in facial and ocular injuries [33, 37-39]. For example, although 93 eye injuries were treated by members of the Canadian Ophthalmologic Society during the 1986-1987 season (compared with 257 in 1974-1975), with 18 instances of legal blindness (compared with 43 in 1974-1975), no eye injuries were sustained by players wearing Canadian Standard Association approved face shields [38]. Several of the studies reviewed in this chapter have shown that the use of protective face shields has been associated with a dramatic decrease in the incidence of eye, facial, and dental injuries. Reynen and Clancy [36] reported that the United States has prevented approximately 420,000 eye injuries and saved roughly $\$ 60$ million in medical expenses from 1982-1988 as a result of enforcing these rules. Despite such policy changes, head injuries remain a major area for concern across many different age groups and levels of play. Brust et al. [15] ascertained that head injuries accounted for $13.6 \%$ of the total reported injuries 
sustained by children 9-15 years from 9 community teams in Minnesota during the 1990-1991 season. Gerberich et al. [7] studied injury rates among 263 hockey players from 12 US high schools during the 1982-1983 seasons and found that $22 \%$ of the total reported injuries were to the head and neck. Kelly et al. [40] retrospectively reviewed medical records from five emergency departments in Edmonton, Alberta to examine the epidemiology of sport-related head injuries (skull fracture, loss of consciousness, or concussion) presenting to the emergency department in 1996-1997; patients $<20$ years old were involved in $66 \%$ of all head injury cases, with $21 \%$ occurring in ice hockey [40].

Although mandatory full face shield rules do reduce the frequency of facial and eye injuries in this sport, an alarming increase in hockey-related cervical spine injuries became apparent soon after the initiation of these policy changes. Subsequently, a Committee on Prevention of Spinal Cord Injuries Due to Hockey was formed in 1981 to rigorously investigate this area. Since its formation, the committee has been distributing surveys/questionnaires every 2 years to Canadian neurosurgeons, orthopedic surgeons, physiatrists, and recently sport medicine physicians to document the frequency of major spinal cord injuries occurring in Canadian hockey. By 1993, 241 fractures and dislocations of the spine were entered into the registry, with or without injury to the spinal cord or nerve roots [34]. The registry also showed that the annual incidence of major spinal injuries, excluding all minor injuries to the neck such as sprains and strains, had markedly increased since 1981, averaging 16.8 cases per year from 1982 to 1993 [34]. More alarming, greater than 50\% of the spinal cord injuries involved permanent damage, and $25 \%$ of the injured players were paralyzed below the level of the injury. Of the 212 cases with adequate documentation, $17.5 \%$ of the athletes were $11-15$ years of age, and $51.9 \%$ were between 16 and 20 years [34]. The main mechanism of hockeyrelated cervical spine injuries was an axial load on the head with a flexed neck during a collision with the boards, goal posts, or another player, forcing the cervical spine into compression [34, 41-45]. The most common site of injury was the C5-C6 region, and burst fractures and fracture-dislocations were the most frequent types of vertebral injuries [34]. In addition, Molsa et al. [46] studied the incidence and mechanisms of ice hockey-related major spinal cord injury in Finland and Sweden from 1980-1996. Six of the sixteen cases involving permanent neurological deficits $(37.5 \%)$ were ice hockey players aged 14-19 years [46].

\section{Time Loss}

Table 8 highlights a comparison of injury severity between several of the selected studies, as measured by time loss from competition, hospitalization, and fractures $[2,3,5,7,11,14,15,17,24,28,29]$. Few studies addressed 
Table 8. A comparison of injury severity among pediatric ice hockey players

\begin{tabular}{|c|c|c|c|c|c|c|}
\hline Study & $\begin{array}{l}\text { Design } \\
\mathrm{P} / \mathrm{R}\end{array}$ & $\operatorname{Age}(\mathrm{s})$ & Year & Number of injuries & Time loss & Hospitalization \\
\hline$[11]$ & $\mathrm{R}$ & $6-15$ & 1980-1982 & $290 / 1,124$ & & $23 / 290$ \\
\hline [28] & $\mathrm{P}$ & $11-19$ & 1993-1994 & $\begin{array}{l}\text { Boys: } 60 \\
\text { Girls: } 4\end{array}$ & $\begin{array}{l}\text { Boys: }>7 \text { d } 18 \% \\
\text { Girls: }>7 \text { d } 0 \%\end{array}$ & \\
\hline [2] & $\mathrm{P}$ & $17-20$ & 1990-1993 & 142 & $\begin{array}{l}\text { *Mild: } 58 \% \\
\text { Moderate: } 36 \% \\
\text { Severe: } 6 \%\end{array}$ & Surgery:2.1\% \\
\hline [7] & $\mathrm{R}$ & Mean: 16.1 & $1982-1983$ & 75 per 100 players & $\begin{array}{l}\text { **Mild: } 54 \% \\
\text { Moderate: } 28 \% \\
\text { Severe: } 18 \%\end{array}$ & \\
\hline$[15]$ & $\mathrm{P}$ & $9-15$ & 1990-1991 & 52 & $\begin{array}{l}\text { "Minimal: } 56 \% \\
\text { Minor: } 27 \% \\
\text { Moderate: } 11 \% \\
\text { Major: } 6 \%\end{array}$ & \\
\hline [3] & $\mathrm{P}$ & $9-14$ & 1993-1994 & 14 & $\begin{array}{l}{ }^{\dagger} \text { Mild: } 57 \% \\
\text { Moderate: } 7 \% \\
\text { Severe: } 36 \%\end{array}$ & \\
\hline [14] & $\mathrm{P}$ & $12-13$ & 1985-1996 & $\begin{array}{l}\text { Fractures } \\
\text { BC (A): } 1 \text { per } 8.2 \\
\text { games } \\
\text { BC }(\mathrm{C}): 1 \text { per } 22.5 \\
\text { games } \\
\text { NBC }(\mathrm{C}): 1 \text { per } 263 \\
\text { games }\end{array}$ & & \\
\hline$[17]$ & $\mathrm{P}$ & $<20$ & 1994 & 29 & $\begin{array}{l}\leq 1 \text { day: } 60.7 \% \\
>1 \text { day, } F L \text {, or } C: 39.3 \%\end{array}$ & \\
\hline
\end{tabular}


Table 8 (continued)

\begin{tabular}{|c|c|c|c|c|c|c|c|}
\hline Study & Design & Age(s) & Year & Number of injuries & Time loss & & \\
\hline \multirow[t]{2}{*}[28]{} & $\mathrm{P}$ & $11-19$ & 1993-1994 & Boys: 60 & Boys: $\leq 1$ day: $57 \%$ & & \\
\hline & & & & Girls: 4 & Boys: $>7$ days: $18 \%$ & & \\
\hline \multirow[t]{4}{*}{ [5] } & & & & $\begin{array}{l}\text { Upper extremity } \\
\text { only }\end{array}$ & $\leq 11$ & $12-14$ & $15-19$ \\
\hline & $\mathrm{R}$ & $\leq 11$ & 1996 & 20 & ${ }^{\dagger}$ Minor: $1 \%$ & Minor: $15 \%$ & Minor: $36 \%$ \\
\hline & & $12-14$ & & 126 & Moderate: $5 \%$ & Moderate: $13 \%$ & Moderate: $39 \%$ \\
\hline & & $15-19$ & & 304 & Major: $1 \%$ & Major: $20 \%$ & Major: $43 \%$ \\
\hline \multirow[t]{3}{*}[24]{} & $\mathrm{R}$ & $14-18$ & 1982-1984 & Shoulder only & ${ }^{\dagger \dagger}$ Minor: 33.3 & & \\
\hline & & & & 45 & Moderate: 37.8 & & \\
\hline & & & & & Major: 15.6 & & \\
\hline \multirow[t]{3}{*}{ [29] } & $\mathrm{P}$ & Mean: & 1997-1998 & 32 & ${ }^{\dagger \dagger}$ Minor: 84.4 & & \\
\hline & & 14.7 & & (females only) & Moderate: 9.4 & & \\
\hline & & & & & Major: 6.3 & & \\
\hline
\end{tabular}

$\mathrm{FL}=$ Facial Laceration, $\mathrm{C}=$ concussion, $\mathrm{BC}(\mathrm{A})=$ body checking, level $\mathrm{AA} ; \mathrm{NBC}(\mathrm{C})=$ no body checking, level $\mathrm{CC} ; \mathrm{P}=$ prospective; $\mathrm{R}=$ retrospective.

*Mild $=\leq 3$ days missed; moderate $=4-14$ days missed; severe $=$ long-term sequela expected and athlete unable to return in same capacity.

$* *$ Mild $=\leq 1$ week time loss; moderate $=1-3$ weeks time loss; severe $=>3$ weeks time loss.

$*$ Minimal $=\leq 1$ day time loss; minor $=2-7$ days time loss; moderate $=8-24$ days time loss; major $=\geq 25$ days time loss.

${ }^{\dagger}$ Mild $=\leq 3$ days missed; moderate $=4-14$ days missed; severe $=$ long-term sequela expected and athlete may be unable to return to play in same capacity.

$\dagger$ Minor $=\leq 7$ days missed; moderate $=8-27$ days missed; major $=\geq 28$ days missed.

${ }^{\dagger \dagger}$ Minor $=<1$ week missed; moderate $=1-3$ weeks missed; major $=>3$ weeks missed. 
injury severity due to the retrospective designs, definitions of injury, and failure to collect time loss information. Among the studies which classified various degrees of severity, large time loss discrepancies made comparison of studies difficult. Hockey-related injuries were the most common of all sport injuries leading to hospitalization among children aged 6-15 years treated in the Turku University Central Hospital Casualty Department from 1980 to 1982 (23/102) [11].

\section{Injury Risk Factors}

Specific ice hockey-related injury risk factors are poorly delineated and rarely studied in the pediatric ice hockey literature. Size differences between players competing at the Minor hockey level of competition was one potential risk factor for injury. Weight and height differences between the smallest and largest Bantam hockey players were shown to be $53 \mathrm{~kg}$ and $55 \mathrm{~cm}$, respectively [15]. Weight differences were statistically significant, and lighter players were more likely to be injured. In addition, a statistically significant increase in injuries was associated with age, with $54 \%$ of the injuries sustained by Bantam players (ages 13-15), 27\% by Peewee players (ages 11-13), and 19\% by Squirts (ages 9-11) [15]. Roy et al. [18] evaluated morphologic and strength differences between eight of the smallest and eight of the largest players competing at the Pee-Wee level of competition (12-13 years) during the 1985-1986 season in Quebec city. The average weight and height differences were $37.2 \mathrm{~kg}$ and $31.5 \mathrm{~cm}$, respectively [18]. Furthermore, Bernard et al. [19] found a $357 \%$ difference in the force of impact during body checking between the weakest and strongest player participating at the Bantam level of competition (14-15 years) [19].

\section{Suggestions for Injury Prevention}

Generally, prevention of injury is multifactorial. Because of the inherent characteristics of ice hockey, injuries are unlikely to be eliminated entirely, regardless of the risk-management strategy employed. Once this is recognized, strategies can be aimed at avoiding unnecessary foreseeable risk, and controlling that which is understood to be inherent to the sport [47]. That said, it is extremely important for sports governing bodies to 'do their homework' prior to introducing new risk management strategies to make sure that preventive strategies do not result in other adverse health effects. Also, once specific actions are taken such as the introduction of a new rule or equipment standard, 
it is important that sport epidemiologic research continues to assess the effectiveness of the preventative program. Products should be improved and standards changed concurrently with the new experience gained [48].

\section{Protective Equipment}

The introduction of mandatory full face shield rules among the pediatric population has dramatically reduced the rate of facial and eye injuries. Until recently, there was controversy that the added protection would increase other injury rates due to a feeling of invincibility leading athletes to take excessive and unwarranted risks. Gerberich et al. [7] found that $66 \%$ of high school hockey players from the Minnesota area felt that the requirement of the face mask allowed them to be more aggressive in their style of play. However, data exists in the adult epidemiologic literature to support the protective effect of full face shield use in reducing concussion severity, facial, eye and dental injuries, without increasing other injury rates overall $[49,50]$. Whether or not reduced concussion severity with no change in overall injury rates would hold for skeletally immature individuals is not known; however, it would be unethical to find out by putting young athletes at increased risk of injury with the removal of the full face shield. Presently, full face shield use is mandated by all organized Minor hockey associations worldwide.

Mouthguard use has also been mandated by several European amateur leagues, the United States Amateur Hockey Association, High School hockey, Junior hockey, and the Peewee level and higher in Canadian Minor hockey for the purpose of reducing the incidence of dental and concussive head injuries. Although the benefits of mouthguard use in protecting athletes from dental injury is supported in the literature [51-59], controversy exists as to whether mouthguard use can reduce athletes' risk of concussion. The evidence of a protective effect on concussions stemmed primarily from a limited number of case series and retrospective cross-sectional surveys. Some authors have stated that the most important value of mouthguard use in sport is the concussion-saving effect following impact with the mandible [53,54,60]. Despite lacking clinical application and study, this notion has influenced decision making regarding mouthguard use in sports. At this stage, there is no valid scientific evidence of an association or lack of association between mouthguard use and reduced concussion risk.

A custom-fitted mouthguard (type III) has been reported to be necessary to ensure retention of the mouthguard in collision or contact sports; the simpler designs do not afford much protection, tend to fit poorly, and often interfere with breathing and speech [61]. An optimal mouthguard thickness of four millimeters at the occlusal surface is recommended [54]. It has been shown that the thickness before and after moulding custom-fitted mouthguards decreases 
by $25-50 \%$ [54]. For type II, or commercial 'boil-and-bite' mouthguards, the thickness decreases by $70-99 \%$ at the occlusal surface; this is attributed to a lack of control of pressure exerted by the wearer during fitting [54]. Their advantage lies in their cheap cost and wide-spread availability. The American Society of Testing Materials standard (F697) for the care of mouthguards states that it should be washed in cold or lukewarm soapy water, stored in rigid containers, and replaced when splits appear. In addition, mouthguards should be replaced every 2 years for adults and every 6 months for children up to 16 years of age due to changes in the developing pediatric jaw, including teeth replacement and changes in the size and shape of gums [54].

Anecdotally, suggestions have also been made to improve padding of the shoulder, wrist/hands, and anterior knee, as well as improvements in the helmet, chin strap, and chin piece of full face shields to help further reduce ice hockey injuries to the respective anatomic areas $[2,5,50]$.

\section{Rink Demographics}

Watson et al. [16] investigated the associations between ice surface size and injuries and aggressive penalties among 328 injured players (16-20 years of age) from 16 teams participating in Canadian Junior hockey. The rates of injury per game were inversely related to ice surface sizes (larger than standard: 0.33 , standard: 0.58 , smaller than standard: $0.76 ; \mathrm{p}<0.01$ ). There was no significant association between penalty rates and ice surface. While the standard size of North American arenas has remained constant $(200 \times 85 \mathrm{ft})$, there has been an increase in size and speed of players. This presumably leads to greater impact forces between players and with the boards, thereby increasing injury potential. Increasing the ice surface would logically decrease contact between players which may reduce injury rates [16]. In 1989, USA Hockey moved the goal line farther from the end boards in an effort to reduce injuries [34]; whether or not this has in fact led to a decrease in injury rates is not known. In addition, injury rates associated with changes in the material composition of the boards (to facilitate energy absorption) and seamless Plexiglas needs to be investigated [7].

\section{Coaching, Officiating, and Rules}

The style of ice hockey has been evolving into a more aggressive sport and illegal actions are evident in every level of competition, ranging from minor hockey to the National Hockey League. The attitude of players needs to focus on fun, skill, and sportsmanship. Although coaches have been shown to believe sportsmanship is very important, only 59\% of players aged 9-15 years from 9 minor hockey teams in the Minnesota area believed that sportsmanship was very important, with older players believing it less [15]. Respect for the fellow 
player must be emphasized in the sport through strict officiating rules which have severe consequences for any individual who deliberately attempts to injure another player through an illegal action such as slashing, checking from behind, high sticking, cross-checking, elbowing, and hits to the head. In addition, referees must maintain strict rule enforcement at all levels of competition to help prevent the release of dangerous mechanical energy exchanges. Because catastrophic injuries most commonly result from illegal play [43], this cannot be overstated. In a published guest editorial, Pashby et al. [62] proposed a 'no head-checking rule' to be implemented in all levels of hockey and in all locations where ice hockey is played to help decrease concussive head injury rates.

Roberts et al. [17] studied game injury rates among 273 high school hockey players from 16 teams competing in an ice hockey tournament and compared the injury rates and penalties assessed under fair-play rules (i.e., competing teams have points added to the tournament point totals for staying under a pre-established limit of team penalties per game) and regular rules. They showed a 4.8:1 ratio of injury rates causing greater than one day time loss, facial lacerations, or concussions among players competing under regular rules versus fair-play rules. In addition, the number of penalties assessed per game averaged 7.1 penalties during fair-play rules and 13 penalties during the regular-rules competition [17].

Whether or not body checking should be allowed at various levels of minor hockey has been a topic of controversy for several years. This stems primarily from size differences between players during the adolescent years when the athlete is vulnerable to epiphyseal injury which has the potential to disrupt growth. In 1976, Quebec and Nova Scotia abolished body-checking for Pee-Wee level players 12 years old and younger [14]. This was soon followed by the provinces of British Columbia, Manitoba, and Ottawa. In 1980, the Canadian Amateur Hockey Association introduced a national rule banning body-checking for all Canadian Pee-Wee hockey players. In 1985, the Canadian Amateur Hockey Association decided to raise all age groups by one year to allow Midget level players (15-16 years) the opportunity to complete high school in their home towns prior to playing junior hockey [14]. With the age change, the Canadian Amateur Hockey Association reconsidered the 'no body-checking' rule, and all provinces with the exception of Nova Scotia allowed body-checking for Pee-Wee players (now 12-13 year olds) for the 1985-1986 season [14].

In 1995, USA Hockey instituted a new rule which made it a penalty if a player completed a check on an opponent who no longer had control of the puck [34]. Another risk management strategy that may effectively reduce injuries in the pediatric population would be to add another referee for games, similar to that introduced by the National Hockey League. Each official could 'patrol' one end of the ice on each side of the red line, catching infractions such as slashing, high sticking, cross-checking, and checking from behind, that 
might otherwise go unnoticed. This 'extra set of eyes' may also make players more cautious of their actions. Lastly, all official hockey associations should seriously consider mandating all coaches and referees to be certified in basic first aid training before participation. This risk management strategy may help prepare these individuals to more effectively deal with injuries in leagues that do not normally have trained medical personnel readily available.

\section{Injury Surveillance}

Validated, comprehensive reporting and recording systems to identify injury trends and potential risk factors associated with injury for players at various levels of amateur hockey is critical so that strategies for prevention and control of injuries may be developed based on evidence. There are several athletic injury reporting systems currently in place. However, it is crucial to be able to compare data from different sources to advance our understanding of athletic injury epidemiology. Meeuwisse and Love [63] reviewed existing athletic injury reporting systems in North America and offered four recommendations to assist in moving toward more universal systems for athletic injury reporting. First, comparability of data between systems should be maximized through clear indication of the reporting system design and the methods of data collection. Secondly, an exact definition should be given as to what constitutes a reportable event (injury). Thirdly, whenever possible, outcome information should be collected on each reported event so that an injury definition may be applied at the time of data analysis. Finally, any limitations or sources of error should be acknowledged [63].

\section{Public Awareness}

There has been increasing concern, both public and professional, about the frequency and severity of concussions occurring in ice hockey. The morbidity of severe injuries to the brain is a major public health problem, particularly among the pediatric population, because many athletes who sustain these injuries have persistent symptoms or neuropsychological deficits that result in social dysfunction, lost productivity, and excessive health care costs [64-66]. There is also evidence to suggest that cumulative brain damage may be associated with repeated concussions [64-66].

Social and psychological factors among young hockey players include increased aggressiveness and willingness to take risks, a feeling of invincibility, and a lack of awareness of the possibility of spinal cord injury in hockey [34]. Samuel and Joseph [20] showed that $25 \%$ of 103 patients aged $7-18$ years presenting to a children's hospital emergency department with a hockey-related injury felt that their equipment made spinal cord injury impossible, and nearly $50 \%$ felt that their equipment made brain injury impossible. Furthermore, 32\% 
of patients stated that they would check illegally to win, and $6 \%$ stated that they would purposely injure [20]. Brust et al. [15] showed that only $50 \%$ of the 12-15-year-old players studied understood the seriousness of checking another player from behind, and some of them were still willing to do it. Players must be informed of the potential risks of injury associated with collision forces to the head and neck. Intensive educational programs for coaches, players and parents should become an integral part of this sport to facilitate understanding of these risks [7]. Hockey associations should provide information brochures on injury prevention that are based on evidence.

Many cases of cervical spine injuries were the result of illegal pushing or checking from behind [34, 42, 43]. In 1985, the Canadian Amateur Hockey Association introduced specific rules against pushing or checking from behind, and in 1988 a videotape entitled 'Smart Hockey with Mike Bossy' strongly delivered the safety message [34].

Four major 'position/policy statements' regarding player safety in the sport of ice hockey have been put forth by the American Osteopathic Academy of Sports Medicine (2002), the Canadian Academy of Sport Medicine (1988), and Committee on Sports Medicine and Fitness of the American Academy of Pediatrics (2000), respectively. A summary of the recommendations by American Osteopathic Academy of Sports Medicine were as follows:

(1) Education of all hockey personnel, especially players and coaches, of each of the following:

(a) the potential catastrophic injuries that can occur due to checking from behind, high sticking, and blows to the head, and

(b) the risk, consequences, and prevention of spinal injury, eye injury, and concussion.

(2) Implementation of the Heads Up Hockey safety program by USA Hockey on a larger scale. The Heads Up Hockey brochure and video should be required reading and viewing for all players aged 19 and under, as well as their coaches.

(3) Mandatory full-face shield protection at all amateur levels.

(4) More extensive research into protective equipment.

(5) Continued research into rink technology, particularly safer boards.

(6) The use of larger ice surfaces, and continued experimentation with 4-on-4 play.

(7) Recognition that checking is an acquired skill that needs to be taught in a developmental fashion by qualified coaches.

(8) Recognition that prevention (by playing clean hockey) is the best strategy, and the most important person to teach this to players is the coach.

(9) A formally scheduled meeting between medical and coaching staff each preseason. 
(10) Automatic game suspensions for certain rule violations, including but not limited to checking from behind, violent stick use, blows to the head, and fighting. Suspensions should increase with subsequent violations by the same player [67].

The American Academy of Pediatrics (2000) recommended limiting checking in hockey players 15 years of age and younger as a means to reduce injuries [4]. They also stated that strategies such as the 'fair play concept' may also help decrease injuries that resulted from penalties or unnecessary contact. In addition, the Canadian Academy of Sport Medicine (1988) put forth six recommendations after reviewing the ice hockey injury literature:

(1) A nationwide system for collection and classification of injury data be established.

(2) Body checking be eliminated from levels of minor hockey which are not designed as training for professional and international ranks.

(3) Fighting be completely eliminated from the game of hockey.

(4) A major educational program be undertaken aimed at coaches, trainers, players and parents to deinstitutionalize the current accepted norms of violence and injury.

(5) Increased enforcement of existing rules designed to prohibit unsafe acts is required immediately.

(6) Recreational and old-timer's hockey be brought under regulation to conform to equipment standards for safety [68].

Finally, Canadian Academy Sport Medicine (2000) published a position statement regarding facial protection in ice hockey. Their recommendations were as follows:

(1) All ice hockey participants at all levels wear facial protection. Visors (half face shield) significantly reduce the risk of eye injury, but full facial protection has virtually eliminated facial injury. Referees and linesmen should wear helmets and facial protection which will still allow them to blow the whistle.

(2) Only Canadian Standard Association certified equipment be used.

(3) Equipment must be properly fitted and worn. Helmets should be done up securely (no more than two finger-breadths between the neck and the chin strap). Players should not be allowed to play unless they are wearing their helmet and facial protection appropriately [69].

\section{Suggestions for Further Research}

Epidemiologic research contributes to an increased understanding of the incidence and mechanism of injury for specific populations with the ultimate 
purpose of reducing risk. Specific hockey-related injury risk factors are poorly delineated and rarely studied among pediatric ice hockey players leaving large gaps in the knowledge of appropriate prevention strategies. Potential risk factors for injury must be investigated using sound epidemiological principles to provide credible information [2]. One such example is mouthguard use and concussion risk. Given the world-wide pediatric use of full-face shields providing athletes with dental injury protection, it would be prudent to investigate the potential protective effect of mouthguard use on concussions to determine whether mouthguard use in combination with a full face shield is necessary. In addition, future research should be conducted to determine whether increasing the 'cushioning' of the boards can modify basic qualities of the mechanical energy exchange when a player is checked into the boards, a leading mechanism shown to cause injury in this review. This may help a player's neck decelerate the kinetic energy of their torso after a head-first impact. However, it is important to make sure that this increased 'cushioning' does not decelerate the puck to the point where it no longer rebounds; this may potentially increase player congestion along the boards and subsequently increase injury rates. Furthermore, studies should be conducted to determine whether injury rates can be reduced by increasing athletes' awareness that they are in a vulnerable area for injury, such as a 'danger' line painted approximately 3 feet away from the boards around the circumference of the ice surface or a 'stop sign' on the back of players' jerseys. This could easily be studied in amateur hockey.

Gilder and Grogan [70] studied the effects of strength and conditioning drills on injury rates among junior hockey players and showed that endurance, strength, and power drills can increase the integrity of joints and durability of the muscles to help handle physical contact. Future research should be conducted specifically to determine whether such programs can increase players' resistance to injury.

It is critical that future well-designed, prospective studies of sufficient power incorporate a specific target population, use a strict definition of injury and injury severity, use qualified personnel making the injury diagnoses, and use a validated system of injury surveillance. Accurate athlete-participation (exposure) data measuring each athlete's daily participation, as well as specific risk factor exposure information during practices and games should be collected so that the actual risk of injury associated with a potential risk factor can be determined. This information not only will be important to the athletes' themselves, but crucial for sports governing bodies responsible for player safety and physicians who must provide advice to athletes regarding injury prevention. 


\section{References}

1 Marchie A, Cusimano MD: Bodychecking and concussions in ice hockey: Should our youth pay the price? Can Med Assoc J 2003;169:124-128.

2 Stuart MJ, Smith A: Injuries in junior A ice hockey: A three-year prospective study. Am J Sports Med 1995;23:458-461.

3 Stuart MJ, Smith AM, Nieva JJ, Rock MG: Injuries in youth ice hockey: A pilot surveillance strategy. Mayo Clin Proc 1995;70:350-356.

4 Committee on Sports Medicine and Fitness, American Academy of Pediatrics: Safety in youth ice hockey: The effects of body checking. Pediatrics 2000;105:657-658.

5 Molsa J, Kujala U, Myllynen P, Torstila I, Airaksinen O: Injuries to the upper extremity in ice hockey: Analysis of a series of 760 injuries. Am J Sports Med 2003;31:751-757.

6 Daly PJ, Sim FH, Simonet WT: Ice hockey injuries: A review. Sports Med 1990;10:122-131.

7 Gerberich SG, Finke R, Madden M, Priest JD, Aamoth G, Murray K: An epidemiological study of high school ice hockey injuries. Childs Nerv Syst 1987;3:59-64.

8 Cantu R: Reflections on head injuries in sport and the concussion controversy (editorial). Clin J Sport Med 1997;7:83-84.

9 Last J: A dictionary of epidemiology. ed 4. 2001, New York, Oxford University Press, Inc.

10 Pinto M, Kuhn J, Greenfield M, Hawkins R: Prospective analysis of ice hockey injuries at the junior level over the course of one season. Clin J Sport Med 1999;9:70-74.

11 Kvist M, Kujala UM, Heinonen OJ, Vuori IV, Aho AJ, Pajulo O, Hintsa A, Parvinen T: Sportsrelated injuries in children. Int J Sports Med 1989;10:81-86.

12 Bjorkenheim JM, Syvahuoko I, Rosenberg PH: Injuries in competitive junior ice-hockey: 1437 players followed for one season. Acta Orthop Scand 1993;64:459-461.

13 Park RD, Castaldi CR: Injuries in junior ice hockey. Phys Sportsmed 1980;8:81-90.

14 Regnier G, Boileau R, Marcotte G, Desharnais R, Larouche R, Bernard D, Roy MA, Trudel P, Boulanger D: Effects of body-checking in the pee-wee (12 and 13 years old) division in the province of Quebec; in Castaldi CR, Hoerner EF (eds): Safety in Ice Hockey, ASTM STP 1050. Philadelphia, American Society for Testing and Materials, 1989, pp 84-103.

15 Brust JD, Leonard BJ, Pheley A, Roberts WO: Children's ice hockey injuries. Am J Dis Child 1992;146:741-747.

16 Watson RC, Nystrom MA, Buckolz E: Safety in Canadian junior ice hockey: The association between ice surface size and injuries and aggressive penalties in the Ontario hockey league. Clin J Sport Med 1997;7:192-195.

17 Roberts W, Brust J, Leonard B, Hebert B: Fair-play rules and injury reduction in ice hockey. Arch Pediatr Adolesc Med 1996;150:140-145.

18 Roy M, Bernard D, Roy B, Marcotte G: Body checking in pee wee hockey. Phys Sportsmed 1989;17:119-126.

19 Bernard D, Trudel P, Marcotte G, Boileau R: The incidence, types, and circumstances of injuries to ice hockey players at the bantam level (14 to 15 years old); in Castaldi CR, Bishop PJ, Hoerner EF (eds): Safety in Ice Hockey: Second Volume, ASTM STP 1212. Philadelphia, American Society for Testing and Materials, 1993, pp 44-55.

20 Samuel R, Joseph D: Factors associated with significant injuries in youth ice hockey players. Pediatr Emerg Care 1999;15:310-313.

21 Goodman D, Gaetz M, Meichenbaum D: Concussions in hockey: There is a cause for concern. Med Sci Sports Exerc 2001;33:2004-2009.

22 Stuart M, Smith A, Malo-Ortiguera S, Fischer T, Larson D: A comparison of facial protection and the incidence of head, neck, and facial injuries in Junior A hockey players. Am J Sports Med 2002;30:39-44.

23 Smith A, Stuart M, Wiese-Bjornstal D, Gunnon C: Predictors of injury in ice hockey players: A multivariate, multidisciplinary approach. Am J Sports Med 1997;25:500-507.

24 Finke R, Gerberich S, Madden M, Funk S, Murray K, Priest J, Aamoth G: Shoulder injuries in ice hockey. J Orthop Sports Phys Ther 1988;10:54-58. 
Sutherland G: Fire on ice. Am J Sports Med 1976;4:264-269.

de Loes M: Epidemiology of Sports Injuries in the Swiss Organization 'youth and sports' 1987-1989. Int J Sports Med 1995;16:134-138.

Montelpare WJ: Final report to the Ontario hockey federation and the Canadian hockey association: Measuring the effects of initiating body checking at the atom age level. 2001, www.bcaha.org/mailouts/2002-07-28/2002-19-Iatt\%20Bodychecking\%20Report\% 202002-07-18.pdf.

Roberts WO, Brust JD, Leonard B: Youth ice hockey tournament injuries: Rates and patterns compared to season play. Med Sci Sports Exerc 1999;31:46-51.

Dryden D, Francescutti L, Rowe B, Spence J, Voaklander D: Epidemiology of women's recreational ice hockey injuries. Med Sci Sports Exerc 2000;32:1378-1383.

Castaldi CR: Sports-related oral and facial injuries in the young athlete: A new challenge for the pediatric dentist. Pediatr Dent 1986;8:311-316.

Pashby T, Pashby R, Chisholm L, Crawford J: Eye injuries in Canadian hockey. Can Med Assoc J 1975;113:663-666.

Pashby T: Eye injuries in Canadian hockey. Phase II. Can Med Assoc J 1977;117:670-678.

Pashby T: Eye injuries in Canadian amateur hockey. Can J Ophthalmol 1985;20:2-4.

Tator C, Carson J, Edmonds V: New spinal injuries in hockey. Clin J Sport Med 1997;7:17-21.

Vinger P, Bentkover J, Sullivan R, Kalin J: The ice hockey face guard: Health care costs and ethics; in Castaldi C, Hoerner E (eds): Safety in Ice Hockey, ASTM STP 1050. Philadelphia, American Society for Testing and Materials, 1989, pp 58-62.

Reynen R, Clancy W: Cervical spine injury, hockey helmets, and face masks. Am J Sports Med 1994;22:167-170

Pashby T: Eye injuries in Canadian ice hockey, phase III, older players now most at risk. Can J Ophthalmol 1979;121:643-644.

Pashby T: Eye injuries in Canadian amateur hockey: Still a concern. Can J Ophthalmol 1987;22:293-296

Pashby T: Making hockey safer (letter). Can Med Assoc J 1990;142:924.

Kelly K, Lissel H, Rowe B, Vincenten J, Voaklander D: Sport and recreation-related head injuries treated in the emergency department. Clin J Sport Med 2001;11:77-81.

Tator C, Edmonds V: National survey of spinal injuries in hockey players. Can Med Assoc J 1984;130:875-880.

Tator C, Ekong C, Rowed D, Schwartz M, Edmonds V, Cooper P: Spinal injuries due to hockey. Can J Neurol Sci 1984;11:34-41.

Tator C, Edmonds V, Lapczak L, Tator I: Spinal injuries in hockey players, 1966-1987. Can J Surg 1991;34:63-69.

Tator C, Carson J, Cushman R: Hockey injuries of the spine in Canada, 1966-1996. Can Med Assoc J 2000;162:1-3.

Torg J: Epidemiology, pathomechanics, and prevention of athletic injuries to the cervical spine. Med Sci Sports Exerc 1985;17:295-303.

Molsa J, Tegner Y, Alaranta H, Myllynen P, Kujala U: Spinal cord injuries in ice hockey in Finland and Sweden from 1980-1996. Int J Sports Med 1999;20:64-67.

Clarke KS: Cornerstones for future directions in head/neck injury prevention in sports; in Hoerner EF (ed): Head and Neck Injuries in Sports, ASTM STP 1229. Philadelphia, American Society for Testing and Materials, 1994, pp 3-9.

Odelgard B: The development of head, face, and neck protectors for ice hockey players; in Castaldi C, Hoerner E (eds): Safety in Ice Hockey. Philadelphia, American Society for Testing and Materials, 1989, pp 220-234.

Benson B, Rose M, Meeuwisse W: The impact of face shield use on concussions in ice hockey: A multivariate analysis. Br J Sports Med 2002;36:27-32.

Benson B, Mohtadi N, Rose M, Meeuwisse W: Head and neck injuries among ice hockey players wearing full face shields vs half face shields. JAMA 1999;282:2328-2332.

Heintz W: The case for mandatory mouth protectors. Phys Sportsmed 1975;April:61-63.

Chapman P: Communication: The bimaxillary mouthguard: Increased protection against orofacial and head injuries in sport. Aust J Sci Med Sport 1985;17:25-29. 
53 Chapman P: Orofacial injuries and the use of mouthguards by the 1984 Great Britain rugby league touring team. Br J Sports Med 1985;19:34-36.

54 Chalmers D: Mouthguards: Protection for the mouth in rugby union. Sports Med 1998;25: 339-349.

55 Cummins N, Spears I: The effect of mouthguard design on stresses in the tooth-bone complex. Med Sci Sports Exerc 2002;34:942-947.

56 Mastrangelo F: Eye and face injuries in high school hockey: cutting down the risks; in Castaldi C, Hoerner E (eds): Safety in Ice Hockey, ASTM STP 1050. Philadelphia, American Society for Testing and Materials, 1989; pp 52-54.

57 Labella C, Smith B, Sigurdsson A: Effect of mouthguards on dental injuries and concussions in college basketball. Med Sci Sports Exerc 2002;34:41-44.

58 Ranalli D, Demas P: Orofacial injuries from sport: Preventive measures for sports medicine. Sports Med 2002;32:409-418.

59 Newsome P, Tran D, Cooke M: The role of the mouthguard in the prevention of sports-related dental injuries: A review. Int J Paediatr Dent 2001;11:396-404.

60 Chapman P: Concussion in contact sports and importance of mouthguards in protection. Aust J Sci Med Sport 1985;17:23-27.

61 McCrory P: Do mouthguards prevent concussion? Br J Sports Med 2001;35:81-82.

62 Pashby T, Carson J, Ordogh D, Johnston K, Tator C, Mueller F: Eliminate head-checking in ice hockey. Clin J Sport Med 2001;11:211-213.

63 Meeuwisse W, Love E: Athletic injury reporting. Development of universal systems. Sports Med 1997;24:184-204.

64 NIH consensus development panel on rehabilitation of persons with traumatic brain injury. Rehabilitation of persons with traumatic brain injury. JAMA 1999;282:974-983.

65 Matser E, Kessels A, Lezak MD, Jordan BD, Troost J: Neuropsychological impairment in amateur soccer players. JAMA 1999;282:971-973.

66 Vollmer D, Dacey RJ: The management of mild and moderate head injuries. Neurosurg Clin N Am 1991;2:437-455.

67 Juhn M, Brolinson P, Duffey T, Stockard A, Vangelos Z, Emaus E, Maddox M, Boyajian L, Henehan M: Position statement: Violence and injury in ice hockey. Clin J Sport Med 2002;12:46-51.

68 Canadian Academy of Sport Medicine. Violence and injuries in ice hockey: Position statement. 1988:Gloucester, Ontario.

69 Canadian Academy of Sport Medicine Sport Safety Committee. Use of facial protection in ice hockey. Clin J Sport Med 2000;10:212-213.

70 Gilder K, Grogan J: Prevention of ice hockey injuries by strength and conditioning; in Castaldi C, Bishop P, Hoerner E (eds): Safety in Ice Hockey, ASTM STP 1212. Philadelphia, American Society for Testing and Materials, 1993; pp 56-68.

Dr. Brian Benson c/o Dr. Willem Meeuwisse

Sport Medicine Centre, University of Calgary

2500 University Drive N.W., Calgary, Alberta T2N 1N4 (Canada)

Tel. +1 (403) 220 8426, Fax +1 403282 6140, E-Mail meeuwiss@ucalgary.ca 